\title{
ESTUDO DA REGENERAÇÃO E TRANSPLANTE DE MUDAS DE PALMITEIRO (Euterpe edulis MARTIUS) EM DIFERENTES CONDIÇŌES DE PERTURBAÇÃO E LUMINOSIDADE DA FLORESTA ATLÂNTICA (SP)
}

\author{
SÔNIA MARIA SCHAEFER \\ ENGENHEIRA AGRÔNOMA
}

Orientador: Prof. Dr. FÁBIO POGGIANI

Dissertação apresentada à Escola Superior de Agricultura "Luiz de Queiroz", Universidade de São Paulo, para obtenção do título de Mestre en Ciências, Área de concentração: Ciências Florestais.

PIRACICABA

Estado de São Paulo - Brasil

Março - 1999 
Dados Internacionais de Catalogação na Publicação (CIP) DIVISÃO DE BIBLIOTECA E DOCUMENTAÇÃO - Campus "LUiz de Queiroz"/USP

Schaefer, Sônia Maria

Estudo da regeneração e transplante de mudas de palmiteiro (Euterpe edulis Martius) em diferentes condiçōes de perturbação e luminosidade da Floresta Atlántica (SP) / Sônia Maria Schaefer. - - Piracicaba, 1999.

$75 \mathrm{p}$.

Dissertação (mestrado) - - Escola Superior de Agricultura Luiz de Queiroz, 1999. Bibliografia.

1. Ecologia florestal 2. Efeito da luz 3. Extrativismo vegetal 4. Mata Atlántica 5. Muda de palmiteiro 6. Palmeira oleaginosa 7. Regeneração natural 8. Reserva biológica 9. Transplante de planta I. Título 


\section{AGRADECIMENTOS}

- Ao Prof. Dr. Fábio Poggiani pela orientação, constante incentivo, valiosa amizade e confiança depositada.

- Aos professores Paulo Kageyama e José Leonardo Gonçalves pela amizade e valiosas sugestões.

- À pesquisadora e grande amiga Marisa Domingos pelo incentivo e por ter cedido parte de seu valioso tempo para as discussões que em muito enriqueceram o trabalho.

- À pesquisadora e querida amiga Regina Maria de Moraes pelas sugestões, incentivo e principalmente por ter assumido a Encarregatura da Reserva Biológica de Paranapiacaba possibilitando minha participação no curso de mestrado

- Meu agradecimento especial ao Sr. Antônio Victor da Costa, funcionário da Reserva Biológica de Paranapiacaba, pela amizade, incentivo, dedicação e auxílio nos trabalhos de campo.

- À Direção do Instituto de Botânica por ter me concedido o afastamento e à Chefia da Seção de Ecologia por ter facilitado o desenvolvimento do trabalho.

- Aos vigias da Reserva Biológica de Paranapiacaba pela segurança oferecida.

- Ao Escritório da RFFSA - Regional de Paranapiacaba e à MRS Logística pelo fornecimento dos dados de temperatura e precipitação.

- À CAPES pelo apoio financeiro prestado para a realização do trabalho.

- Aos amigos pós-graduandos pelas sugestões, amizade e inesquecíveis horas de descontração. 


\section{SUMÁRIO}

Página

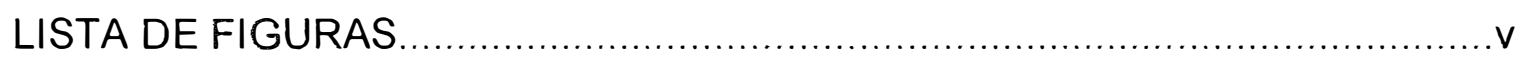

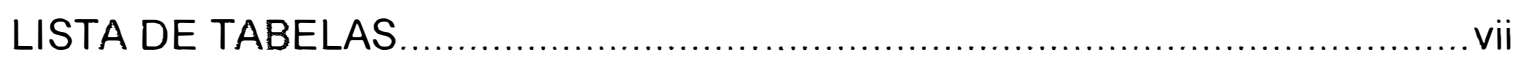

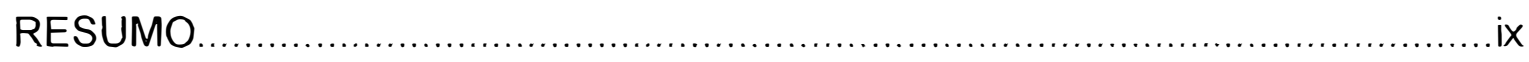

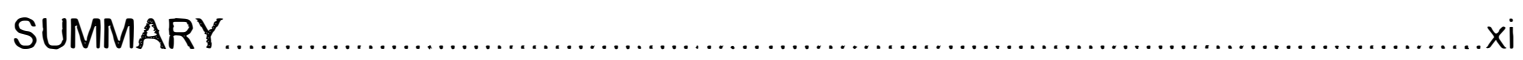

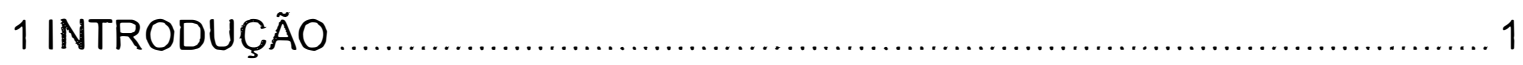

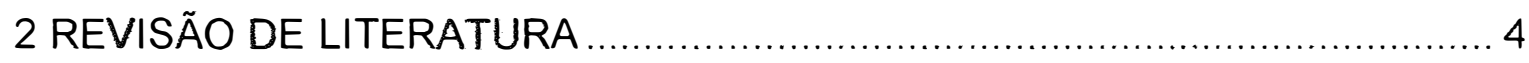

2.1 Características gerais da palmeira Euterpe edulis.................................. 4

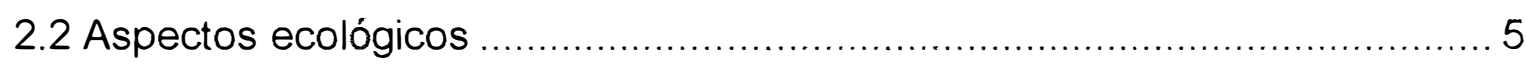

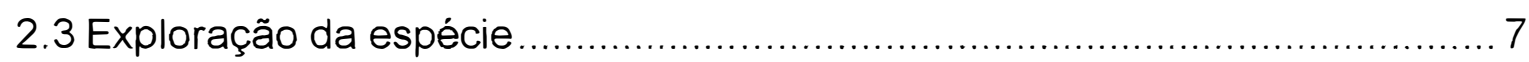

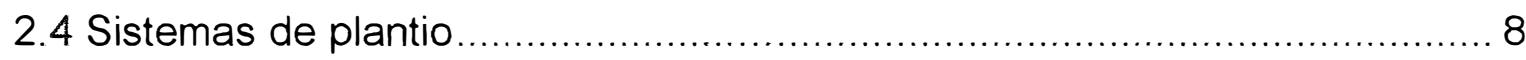

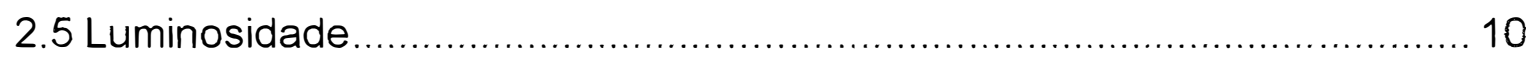

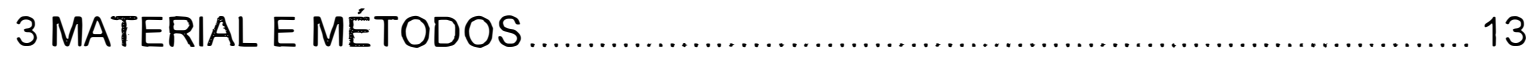

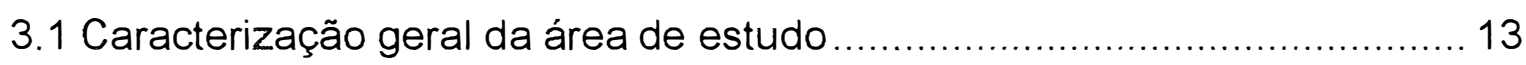

3.2. Avaliação da regeneração natural de Euterpe edulis .............................. 17

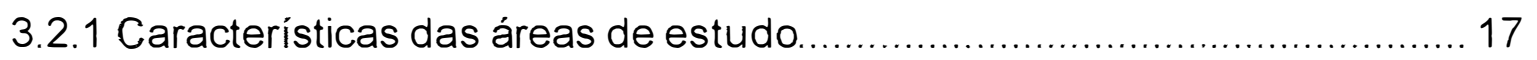

3.2.2 Levantamento da estrutura da população............................................. 18

3.3 Avaliação do método de transplante de mudas de Euterpe edulis ............. 24

3.3.1 Características da área de estudo ..................................................... 24

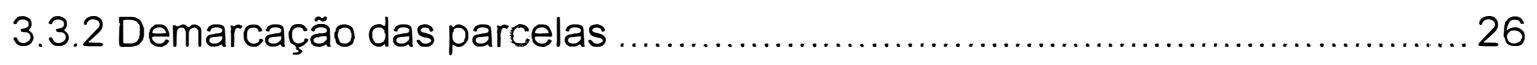

3.3.3 Seleção e plantio das mudas ........................................................... 26

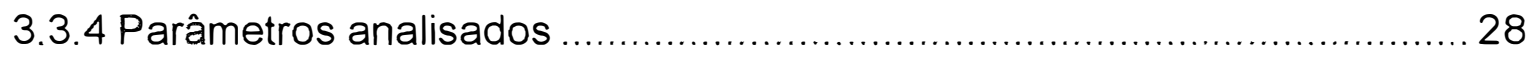

3.3.5 Acompanhamento da intensidade da radiação ....................................... 28

3.3.6 Definição dos tratamentos .................................................................... 31

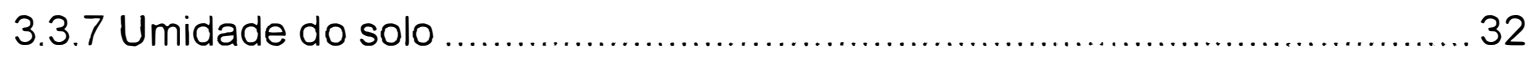

3.3.8 Acompanhamento da temperatura e precipitação .................................. 34 
4 RESULTADOS E DISCUSSÃO

4.1 Avaliação da regeneração natural de Euterpe edulis ................................ 36

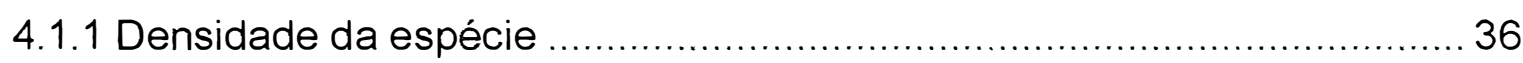

4.1.2 Capacidade reprodutiva da população de palmiteiros ........................... 39

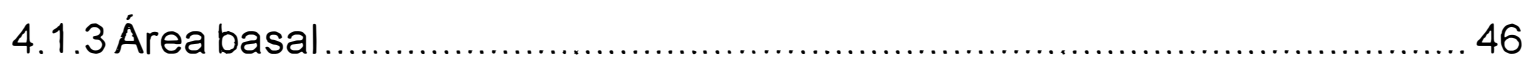

4.2 Avaliação do método de transplante de mudas de Euterpe edulis .............. 50

4.2.2 Variação da intensidade da radiação incidente ...................................... 50

4.2.4 Sobrevivência e crescimento das mudas .............................................. 55

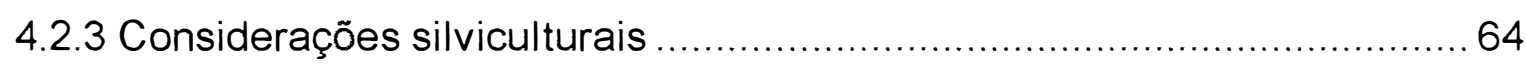

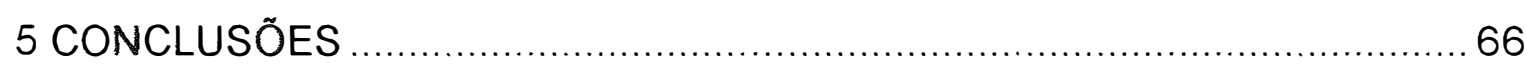

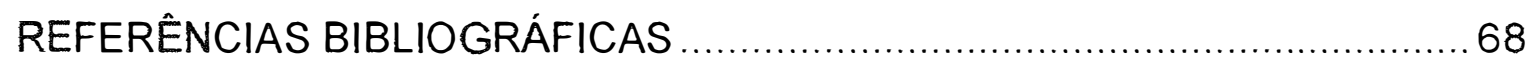




\section{LISTA DE FIGURAS}

Página

1 Posição geográfica da Reserva Biológica de Paranapiacaba, no contexto da Serra do Mar e Baixada Santista.

2 Climadiagrama da região onde está situada a Reserva Biológica de Paranapiacaba, construído segundo a metodologia proposta por Walter (1986). 16

3 Aspecto geral do interior da mata $(A)$ e do dossel (B) da área não perturbada por atividades extrativistas (ANP), utilizada para o levantamento da estrutura da população de Euterpe edulis.

4 Aspecto geral da área perturbada por atividades extrativistas (AP), utilizada para o levantamento da estrutura da população alterada de Euterpe edulis. 20

5 Características de um indivíduo de Euterpe edulis "não encapado" (A) e de um popularmente chamado de "macho" ou "encapado" (B). 23

6 Aspecto geral da muda de Euterpe edulis transplantada para as parcelas amostrais, com diferentes condições de luminosidade, no interior da floresta.

7 Umidade do solo, de 0 a $5 \mathrm{~cm}$ de profundidade, dos tratamentos RA (radiação alta), RM (radiação moderada) e RB (radiação baixa) 
8 Variação da Temperatura média e precipitação total mensais da região de Paranapiacaba, Santo André, SP

9 Comparação entre os diâmetros médios (DAP), calculados por classe de altura, dos individuos amostrados nas áreas não perturbada e perturbada

10 Comparação entre a proporção de individuos jovens, "encapados" e adultos de Euterpe edulis, separados por classe de altura, existentes nas áreas não perturbada e perturbada

11 Número de individuos de Euterpe edulis, separados por DAP, existentes nas áreas não perturbada e perturbada

12 Médias da intensidade da radiação incidente acima das copas das árvores (radiação total), obtidas em 1 dia de cada estação do ano, das $10: 00$ às 14:00 hs, na Reserva Biológica de Paranapiacaba, SP.

13 Médias da intensidade da radiação incidente nos tratamentos RA, RM e RB, obtidas em 1 dia de cada estação do ano, das 10:00 às 14:00 hs

14 Sobrevivência e crescimento das mudas de Euterpe edulis transplantadas nas parcelas dos tratamentos RA (radiação alta), RM (radiação moderada) e RB (radiação baixa). .56

15 Aspecto das mudas de Euterpe edulis, aos 17 meses, evidenciando as diferenças em altura, diâmetro e aparência geral das folhas em cada tratamento: RA, RM e RB. 


\section{LISTA DE TABELAS}

Página

1 Análise química do solo das áreas não perturbada (ANP) e perturbada por extrativismo (AP), nas profundidades de 0 a $10 \mathrm{~cm} \mathrm{e}$ 10 a $20 \mathrm{~cm}$

2 Análise granulométrica do solo das áreas não perturbada (ANP) e perturbada por extrativismo (AP), nas profundidades de 0 a $10 \mathrm{~cm} \mathrm{e}$ 10 a $20 \mathrm{~cm}$.

3 Análise química do solo da área utilizada para instalação do experimento $(A E)$, nas profundidades de 0 a $10 \mathrm{~cm}$ e 10 a $20 \mathrm{~cm}$

4 Análise granulométrica do solo da área utilizada para instalação do experimento $(A E)$, nas profundidades de 0 a $10 \mathrm{~cm}$ e 10 a $20 \mathrm{~cm}$. 25

5 Médias finais das leituras de intensidade de radiação obtidas nas parcelas amostrais onde foram transplantadas as mudas de Euterpe edulis

6 Médias das leituras de intensidade de radiação nos tratamentos RA, RM e RB, onde foram transplantadas as mudas de Euterpe edulis 31

7 Número de indivíduos de Euterpe edulis e diâmetro médio, por classe de altura, encontrados nas áreas não perturbada (ANP) e perturbada $(A P)$ 
8 Área basal de Euterpe edulis e da soma das outras espécies encontradas nas áreas não perturbada (ANP) e perturbada (AP), considerando-se indivíduos com DAP $\geq 10 \mathrm{~cm}$.

9 Área basal de Euterpe edulis e das outras espécies encontradas "mortas em pé" nas áreas não perturbada (ANP) e perturbada (AP), considerando-se individuos com DAP $\geq 10 \mathrm{~cm}$ 49

10 Valores finais de sobrevivência e crescimento das mudas de Euterpe edulis submetidas aos tratamentos RA, RM e RB 58 


\title{
ESTUDO DA REGENERAÇÃO E TRANSPLANTE DE MUDAS DE PALMITEIRO (Euterpe edulis MARTIUS) EM DIFERENTES CONDIÇÕES DE PERTURBAÇÃO E LUMINOSIDADE DA FLORESTA ATLÂNTICA (SP)
}

\author{
Autora: Sônia Maria Schaefer \\ Orientador: Prof. Dr. Fábio Poggiani
}

\section{RESUMO}

A Reserva Biológica de Paranapiacaba, localizada no alto da Serra do Mar, em Santo André, SP, representa uma das porções que restam da Floresta Atlântica no Estado. No entanto, sua preservação tem sido dificultada pelo extrativismo predatório de palmito, que tem provocado alterações na estrutura de sua vegetação, a partir da eliminação de inúmeros palmiteiros (Euterpe edulis Mart.) e da modificação das condições de luminosidade no interior da floresta. Foram objetivos deste estudo: avaliar os danos causados à regeneração natural do palmiteiro e verificar a sobrevivência e o crescimento de suas mudas quando transplantadas para diferentes condições de luminosidade no interior da floresta, através de práticas silviculturais. Para avaliação da regeneração natural, estudou-se a estrutura da população de palmiteiros em duas áreas: uma área perturbada pelo extrativismo e outra não perturbada. Os estudos mostraram que as atividades extrativistas afetaram consideravelmente a regeneração natural da espécie, pois, em $3.450 \mathrm{~m}^{2}$, foram verificadas, na área não perturbada, 92 palmeiras em estádio reprodutivo e 17.664 plântulas, enquanto que na área perturbada, foram verificadas apenas 2 palmeiras em estádio reprodutivo e somente 892 plântulas. Observou-se, ainda, que $81,5 \%$ dos indivíduos jovens de Euterpe edulis da área perturbada apresentam um impedimento mecânico à polinização, fato que poderá retardar a recuperação da área, caso este impedimento seja definitivo. Quanto ao 
transplante das mudas de Euterpe edulis, por meio do remanejamento de plântulas no interior da floresta, foram testados três locais, com diferentes intensidades de radiação fotossinteticamente ativa (PAR), que foram chamados de "Radiação alta" (RA), "Radiação moderada" (RM) e "Radiação baixa" (RB), com valores variando ao redor de 254,$9 ; 24,2$ e $3,7 \mu \mathrm{mol} . \mathrm{m}^{-2} \cdot \mathrm{s}^{-1}$, respectivamente. Os estudos mostraram que o sistema de plantio adotado é técnica e economicamente viável para a recuperação dos locais afetados pelo extrativismo. Os locais sombreados apenas pelas copas das árvores, correspondentes ao tratamento com intensidade moderada de radiação, - mostraram ser ideais para o transplante das mudas. A satisfatória porcentagem de sobrevivência e o bom desenvolvimento das mudas submetidas ao tratamento de intensidade de radiação mais alta, sugerem que as mudas podem ser transplantadas até mesmo para os locais onde o extrativismo provocou a abertura de pequenas áreas de clareiras. O diâmetro, o peso seco da parte aérea, o número e o peso seco das raízes mostraram uma relação positiva com a intensidade de radiação incidente. 


\title{
STUDY OF THE REGENERATION AND TRANSPLANT OF SWEET PALM SEEDLINGS (Euterpe edulis MARTIUS) AT DIFFERENT DISTURBANCE AND LIGHT CONDITIONS OF ATLANTIC FOREST (SP - BRAZIL)
}

\author{
Author: Sônia Maria Schaefer \\ Adviser: Prof. Dr. Fábio Poggiani
}

\section{SUMMARY}

The Biological Reserve of Paranapiacaba, located near Santo André (SP), is a large fragment of Atlantic Forest. Its preservation has been difficulted by the predatory extraction of heart of palm inducing severe alterations in the structure of the vegetation. This study seeks to evaluate the damages caused to the natural sweet palm regeneration and to verify the survival and the growth of its seedlings, when transplanted under different conditions of illumination inside the forest. To evaluate the natural regeneration, it was studied the population structure of $E$. edulis in two areas: an area perturbed by the heart of palm extraction and other undisturbed. The studies showed that the predatory extraction activities affected the natural regeneration of this specie, because, in the area not perturbed by the heart of palm extraction, were verified 92 palm trees in reproductive stadium and 17.664 seedlings. In the perturbed area, were verified only 2 palm trees in reproductive stadium and 892 seedlings. It was also observed, that $81,5 \%$ of the young individuals of $E$. edulis of the disturbed area present a mechanical impediment to the pollination. This fact can delay the ecological recovery of the area. Seedlings of $E$. edulis were transplanted in three sites with different radiation intensity, that were considered as: "High radiation" ( $R A$ ), "Moderate radiation" ( $R M)$ e "Low radiation" ( $R B)$, showing variation around 254,$9 ; 24,2$ and $3,7 \mathrm{~mol} \cdot \mathrm{m}^{-2} \cdot \mathrm{s}^{-1}$, respectively. The results 
indicated that the transplant system is technical and economically viable to recover the forests affected by the heart of palm extraction. The understory areas, with moderate intensity of radiation, showed the best survival for the seedlings transplant. The good development of the seedlings submitted to the higher radiation, suggest that seedlings can be transplanted even to the sites where the extraction of heart of palm originated the gaps in the forest. The diameter, the dry weight of the aerial part, the number and the dry weight of the roots showed a positive relationship with the intensity of incident radiation. 


\section{INTRODUÇĀO}

O Brasil apresenta uma expressiva diversidade de ecossistemas florestais, devido à sua grande área física e diversos tipos de clima e solo existentes em seu território. No entanto, tais ecossistemas vêm sendo explorados de maneira predatória, o que tem causado um processo de simplificação biológica ou a total destruição desses ecossistemas.

As florestas tropicais são caracterizadas por uma alta diversidade biológica, porém, a maneira com que esta alta diversidade está organizada foi ainda pouco estudada, em grande escala de área e de tempo (Kageyama \& Gandara,1994). Por isso, é preocupante o modo acelerado com que estas florestas estão sendo destruídas e os danos causados ao meio ambiente poderão ser irreversíveis, trazendo graves conseqüências no futuro.

Uma das formas encontradas para reduzir o ritmo progressivo de destruição desses ecossistemas foi instituir, legalmente, através do Poder Público, áreas com regimes especiais de proteção e normas especificas de utilização, que foram chamadas de unidades de conservação. Segundo Griffith (1987), os benefícios previstos, quando se criam parques nacionais, reservas biológicas e estações ecológicas, são generalizados em termos de conservação de complexos inteiros de genes. Estas áreas são mantidas como acervos, cabendo à ciência descobrir, algum dia, o valor de certas espécies assim protegidas.

Como o processo de colonização e ocupação do território nacional se iniciou pelas áreas do litoral, a Floresta Atlântica foi a mais prejudicada. Esta 
formação vegetal, que foi praticamente contínua ao longo de grande parte da região litorânea, hoje é representada por manchas disjuntas da antiga floresta, localizadas principalmente em áreas de difícil acesso, de topografia muito acidentada (Leitão Filho, 1987).

A Reserva Biológica de Paranapiacaba, pertencente ao Instituto de Botânica da Secretaria de Estado do Meio Ambiente de São Paulo, localizada no alto da Serra do Mar, em Santo André, SP, representa uma das porções que restam da Floresta Atlântica no Estado. Um dos principais problemas enfrentados pela administração desta unidade é o extrativismo predatório de palmito, que ocorre através da derrubada generalizada de indivíduos de Euterpe edulis, uma palmeira conhecida na região por palmiteiro. Esta atividade ilegal tem dificultado a preservação integral da Reserva Biológica de Paranapiacaba, uma vez que tem provocado alterações na estrutura de sua vegetação, através da eliminação de inúmeras palmeiras e da modificação das condições de luminosidade no interior da floresta.

Os impactos provocados pelo extrativismo afetam niveis distintos da comunidade florestal. A espécie explorada deixa de ter sua estrutura populacional, durante longo período de tempo, devido à retirada principalmente dos indivíduos adultos, o que impede que o banco de plântulas seja suprido anualmente. Quanto ao restante da comunidade, outros problemas a médio e longo prazos serão detectados, principalmente com relação aos animais polinizadores e dispersores, associados à espécie explorada, e aos predadores desses animais (Reis et al., 1992a).

Segundo Reis (1995), nas áreas onde o palmiteiro foi totalmente devastado, a recomposição natural dos estoques da espécie é um processo muito lento, devendo, portanto, sofrer uma intervenção através da regeneração artificial. No entanto, quando se trata de uma unidade de conservação de proteção integral, como é o caso das reservas biológicas, é preciso avaliar os danos causados ao ambiente e comprovar a necessidade da intervenção 
artificial. Caso seja necessária, esta intervenção deve ser a mais moderada possivel, contando com métodos adequados, que não venham a alterar o ecossistema. Sendo assim, são dois os objetivos principais deste trabalho:

a) avaliar a regeneração natural de Euterpe edulis em duas áreas da Reserva Biológica de Paranapiacaba: uma que foi afetada pelo extrativismo de palmito e outra que não sofreu este tipo de interferência.

b) testar o sistema de transplante de mudas de Euterpe edulis como uma possivel opção para a recuperação das áreas afetadas, verificando a sobrevivência e o crescimento de tais mudas quando submetidas a diferentes condiçōes de luminosidade. 


\section{REVISÃO DE LITERATURA}

\subsection{Características gerais da palmeira Euterpe edulis}

A espécie Euterpe edulis Martius, da família Arecaceae (ex Palmae), é uma palmeira conhecida no Estado de São Paulo por vários nomes populares: palmiteiro, palmito, palmito-juçara, juçara, palmito-doce, palmiteiro-doce, palmito-branco ou palmiteiro-branco.

No Brasil, ocorre nos Estados da Bahia (sul), Espírito Santo, Goiás (sul), Mato Grosso do Sul (sul), Minas Gerais (Zona da Mata), Pernambuco, Paraná (leste, norte e oeste), Rio de Janeiro, Rio Grande do Sul, Santa Catarina (leste) e São Paulo (Carvalho, 1994).

Euterpe edulis possui estipe reto, apresentando em média $15 \mathrm{~m}$ de altura e $15 \mathrm{~cm}$ de diâmetro à altura do peito (DAP - 1,30 m do solo). Na fase inicial de crescimento, suas folhas são do tipo palmada, passando, logo em seguida, para a forma pinada (Alves, 1987).

A inflorescência é do tipo panícula, com grande número de ráquilas. Cada ráquila apresenta vários conjuntos de flores monóclinas (tríades), sendo uma feminina entre duas masculinas. A emissão da inflorescência se dá com a queda da folha cuja bainha envolve a mesma, aparecendo uma estrutura envolta em duas brácteas (espatas), que caem após 12 dias, em média (Reis et al., 1993).

O fruto de Euterpe edulis é do tipo drupa, esférico e de coloração violáceo-escuro (Carvalho, 1994). 
Segundo Nogueira (1982), os caiçaras reconhecem, pelas bainhas que envolvem o palmito, três tipos de palmeiras tidos como pertencentes à espécie Euterpe edulis Mart.: o palmito branco, o vermelho e o "macho" ou "encapado". As palmeiras com palmito "encapado" diferenciam inflorescências, mas estas não conseguem ficar expostas aos polinizadores, devido à presença de folhas secas, cujas bainhas ficam aderidas ao corpo do indivíduo, causando um impedimento mecânico para a reprodução (Reis, 1995).

Com relação ao clima, as regiões de ocorrência da espécie podem ser divididas em duas: aquelas que possuem temperatura e precipitação elevadas e aquelas que apresentam temperatura amena e precipitação média, mas bem distribuída durante o ano (Bovi et al., 1987). Para que tenha um crescimento exuberante, o índice pluviométrico deve ser superior a $1.500 \mathrm{~mm}$ anuais (Nogueira, 1982).

De um modo geral, Euterpe edulis não é exigente quanto ao tipo de solo. Nos locais onde a presença de água superficial é acentuada, como em grotões, a concentração de palmiteiros é maior que nas áreas circunvizinhas (Bovi et al., 1987).

\subsection{Aspectos ecológicos}

Euterpe edulis é uma palmeira característica da mata pluvial atlântica. Sua distribuição é bastante regular em toda a floresta, aparecendo tanto em planícies aluviais, como em vales e encostas (Lorenzi, 1992).

É uma espécie clímax, que apresenta grande freqüência e densidade mesmo nas formações secundárias (Carvalho, 1994). Na floresta primária, ocorre de maneira expressiva e muitas vezes dominante no segundo estrato arbóreo. É uma planta perenifólia, esciófita, mesófita ou levemente higrófita (Lorenzi, 1992). 
Sua regeneração natural é intensa, caracterizada pela estratégia de banco de plântulas (Reis et al., 1992b). Variações na velocidade inicial de germinação indicam a formação de um banco de sementes passageiro, que permite a entrada gradual de indivíduos no banco de plântulas (Reis et al., 1992d).

Estimativas da sobrevivência, entre os diversos estádios de desenvolvimento da espécie, variam de 21,61 a $84,38 \%$. O periodo mais crítico para a sobrevivência parece estar entre o estádio de uma folha até $50 \mathrm{~cm}$ de altura, devido à intensa competição por água, luz e nutrientes que ocorre nessa fase (Bovi et al., 1987).

Quanto ao padrão de dispersão em relação ao adulto mais próximo e o padrão espacial de plântulas, Matos (1996) detectou que a maioria das sementes encontra-se na proximidade da planta adulta $(0,6 \mathrm{~m})$. A sobrevivência e crescimento das plântulas é inversamente proporcional à densidade, atingindo valor máximo para distâncias de aproximadamente $4 \mathrm{~m}$ da planta adulta.

Reis (1995), estudando uma população de palmiteiros na Floresta Ombrófila Densa Montana da encosta atlântica, em Blumenau, SC, estimou 25.200 plântulas por hectare e 683 indivíduos com estipe exposto por hectare, sendo que 56 encontravam-se em idade reprodutiva.

Fantini et al. (1993) encontraram 262 plantas de Euterpe edulis, em idade reprodutiva, por hectare, em uma área selecionada para coleta de sementes na Fazenda Intervales, localizada em Sete Barras, SP. Os autores consideraram esta densidade muito alta, o que indica que a área estudada apresenta um bom potencial de produtividade de sementes.

Em um levantamento fitossociológico de um trecho de Mata Atlântica de Encosta, no Parque Estadual da llha do Cardoso, Cananéia, SP, Melo \& Mantovani (1994) verificaram que três espécies se destacaram na contribuição à área basal total: Euterpe edulis $(7,58 \%)$, Cryptocarya moschata $(7,50 \%)$ e 
Virola oleifera $(6,47 \%)$. Euterpe edulis foi a espécie que apresentou o maior indice de valor de importância $(31,13)$, contribuindo com $19,96 \%$ do número total de indivíduos amostrados (501/ha - CAP $\geq 8 \mathrm{~cm}$ ).

Placci et al. (1992), estudando uma área de concentração de palmiteiros, no Parque Nacional "Iguazu", na Argentina, também verificou o maior índice de valor de importância para Euterpe edulis $(23,24)$, a qual contribuiu com $42,5 \%$ do total de indivíduos amostrados (788/ha - com DAP $>5 \mathrm{~cm}$ ) e 19,5\% da área basal total.

\subsection{Exploração da espécie}

O termo edulis significa comestivel e se refere, nesta espécie, ao palmito (Rodrigues, 1994), que é um alimento bastante apreciado na culinária nacional e internacional, sendo utilizado na forma de conserva. Na planta, corresponde ao meristema apical e folhas jovens, das quais as principais partes consumidas são as bainhas (Reis, 1995).

No Estado de São Paulo, como em todo o Brasil, a exploração da palmeira Euterpe edulis tem se caracterizado como uma atividade extrativista (Ribeiro et al.,1994), pois o lento retorno financeiro desestimula o seu cultivo. Como Euterpe edulis é uma planta de estipe único, ou seja, não tem a capacidade de perfilhar, a coleta de cada palmito implica necessariamente na morte da planta. Sendo assim, a maneira irracional como é feita a exploração do palmito, de forma extrativista, sem controle e sem preocupação com a sua regeneração natural, tem causado uma sensivel redução nas populações naturais da espécie (Nogueira, 1982).

Placci et al. (1992) alertam para a preservação das áreas de concentração de palmiteiros do Parque Nacional "Iguazu", cuja estrutura foi afetada pelo corte ilícito de 2.900 palmeiras. Os autores consideraram o 
palmital como uma unidade ambiental de atração da fauna e Euterpe edulis como um exemplo de "espécie chave" dentro do ecossistema.

Reis (1995) verificou acentuados e complexos níveis de interação entre Euterpe edulis e a fauna, nos processos de dispersão primária e secundária, indicando que a espécie é responsável pela nutrição de muitos animais dentro da comunidade florestal, por um longo período de tempo.

A sensivel redução das populações naturais de Euterpe edulis, em virtude das práticas extrativistas, levaram ao estabelecimento de critérios para que a exploração da espécie fosse realizada de forma sustentada. A legislação no Estado de São Paulo exige a manutenção de, no mínimo, 50 palmiteiros por hectare em fase de frutificação, distribuídos o mais homogeneamente possível na área a ser explorada, em regime de manejo sustentado (São Paulo, 1992).

\subsection{Sistemas de plantio}

A implantação da cultura do palmiteiro pode ser feita através de semeadura direta, transplante (remanejamento de mudas na mata) e plantio de mudas envolvendo diferentes condições de cultivo (Bovi et al., 1987).

Nodari et al. (1987), testando diversos sistemas de implantação de palmiteiros em mata secundária, ao longo de nove meses, concluíram que a maior eficiência baseia-se no sistema que utiliza mudas de raiz nua (estádio ainda plântula ou mudas com a primeira folha aberta).

No entanto, Reis et al. (1992c), considerando que tais resultados podem sofrer modificações, a médio e longo prazos, realizaram nova avaliação deste experimento, aos 46 e 52 meses após a implantação. Os autores concluíram que a distribuição de frutos/sementes na superfície do solo é o melhor sistema, pela sua eficiência e baixo custo. Os plantios utilizando mudas ou plântulas com raiz nua, devem ser utilizados quando houver pequena disponibilidade de 
sementes, uma vez que apresentaram maior sobrevivência em relação ao plantio por sementes e frutos.

Todavia, Bovi et al. (1992), testando diferentes profundidades de semeadura de Euterpe edulis, verificaram que a semeadura superficial, obtida pelo método a lanço, apresentou baixa porcentagem final de emergência e sobrevivência nula, a partir do vigésimo sexto mês de implantação. Os melhores resultados foram obtidos para as semeaduras feitas a 2 e $3 \mathrm{~cm}$ de profundidade.

Aguiar \& Silva Filho (1992) abordando a viabilidade do cultivo de Euterpe edulis em mata ciliar, verificaram maior desempenho para o sistema de plantio por mudas, ressaltando, entretanto, que a semeadura direta apresenta um custo inicial de implantação mais econômico.

Segundo Bovi et al. (1987), em condições naturais, as sementes de palmiteiro são mal distribuídas, pois os frutos, quando maduros, caem num raio não superior a 2 metros do estipe. Isso faz com que um número imenso de novas mudas apareçam ao pé da palmeira, porém, poucas sobrevivem e tornam-se adultas, devido à intensa competição por água, luz e nutrientes. Sendo assim, os autores citam o sistema de transplante, através do remanejamento dessas mudas, como uma boa opção para o plantio de Euterpe edulis, uma vez que são aproveitadas mudas que teriam poucas chances de sobreviver. Adotando este sistema de plantio, os autores constataram que mudas grandes (50-100 cm de altura), mudas plantadas com torrão e mudas plantadas em floresta mais sombreada $(70 \%)$, apresentaram maior sobrevivência do que mudas pequenas $(10-20 \mathrm{~cm}$ de altura), mudas com raiz nua e mudas plantadas em floresta menos sombreada (50\%). 


\subsection{Luminosidade}

A estrutura da comunidade tanto afeta a luz como é afetada por ela. A intensidade e a qualidade espectral da luz, que atinge o solo de uma floresta, depende das espécies presentes e da densidade das sucessivas camadas abaixo do dossel (Whatley \& Whatley, 1982). Quanto à regeneração, a presença e o grau de sombreamento da vegetação são críticos (Smith, 1982).

O extrativismo predatório, além de alterar a estrutura populacional da espécie, provoca mudanças na intensidade e na qualidade espectral da luz no interior da floresta. Nos locais de grande concentração de palmeiras, como nos chamados "palmitais", pode ocorrer até mesmo a abertura de clareiras.

Segundo Lee \& Downum (1991), a regiões espectrais de significância biológica incluem os comprimentos de onda: ultra-violetas (UV-B: 280 a $320 \mathrm{~nm}$ e UV-A: 320 a 400 nm); azul (400 a 500 nm); PAR (radiação fotossinteticamente ativa: 400 a $700 \mathrm{~nm}$ ); vermelho (600 a $700 \mathrm{~nm}$, centrado em $660 \mathrm{~nm}$ ); e vermelho extremo (725 a $735 \mathrm{~nm}$, centrado em $730 \mathrm{~nm}$ ).

Chazdon (1986), estudando a intensidade da radiação fotossinteticamente ativa (PAR - 400 a $700 \mathrm{~nm}$ ), em uma floresta tropical úmida da Costa Rica, verificou que as médias de radiação em uma clareira variam de acordo com a estação do ano, a posição relativa da clareira e a margem estudada, sendo que as médias no centro da clareira aumentam com o seu tamanho.

Para Whitmore (1978), quanto maior a clareira, maior a diferença entre o seu microclima e aquele do dossel fechado da floresta, ocorrendo um aumento da quantidade de luz, com mudanças em sua qualidade espectral, um aumento da temperatura e uma diminuição da umidade relativa do ar.

Kageyama et al. (1992) consideram que os conceitos relativos à tolerância e à sucessão (grupos ecológicos) são básicos tanto para as atividades de manejo, quanto para as atividades de reflorestamento. Os 
autores, testando modelos de associações de espécies arbóreas pertencentes a diferentes grupos ecológicos, observaram que a espécie clímax testada, Myroxylon periferum (cabreúva), ao contrário do que se esperava, mostrou um ótimo para seu crescimento, sendo prejudicada no tratamento de maior sombreamento.

Lee et al. (1996), estudando o desenvolvimento de plântulas de árvores da floresta tropical, com diferentes tolerâncias à sombra, verificaram que as características dos grupos foram influenciadas principalmente pela intensidade da luz, mas a qualidade espectral também influenciou caracteres em muitos casos. As espécies intolerantes à sombra foram as que responderam mais fortemente às mudanças na radiação. As espécies com moderada a extrema tolerância à sombra apresentaram respostas individuais consideravelmente variadas, tanto em relação à intensidade quanto à qualidade espectral.

Chazdon (1986), comparando o crescimento de plântulas de três palmeiras: Geonoma cuneata, Asterogyne martiana, e Geonoma congesta, com idades semelhantes, em uma floresta tropical úmida da Costa Rica, em condições de margem de clareira e sub-bosque adjacente (com dossel fechado), verificou que todas as espécies estudadas apresentaram maior produção de folhas e folhas maiores e mais largas na condição de margem de clareira.

Com relação à palmeira Euterpe edulis, a maioria dos estudos sobre sua sobrevivência e crescimento, em relação à luminosidade, está ligada a plantios sob diferentes condições de desbaste de espécies utilizadas em reflorestamentos, graus de abertura ou limpeza de sub-bosque de vegetação natural e sombreamento artificial através da utilização de sombrites.

Yamazoe et al. (1986), estudando a melhor intensidade luminosa para o desenvolvimento de Euterpe edulis sob Pinus pinaster, em São Miguel Arcanjo, $\mathrm{SP}$, constaram que sob maior desbaste de Pinus (80\%), a porcentagem de plantas sobreviventes é inferior aos tratamentos com menor desbaste $(20 \%$, 
$40 \%$ e $60 \%$ ), os quais não diferiram estatísticamente entre si. À conclusão semelhante chegaram Pinheiro et al. (1988), em plantio sob Pinus kesiya, na região de Piracicaba, SP, onde, à exceção do tratamento a pleno sol, cuja mortalidade foi bastante elevada, os demais tratamentos, a $75 \%, 50 \%, 25 \%$ e sem desbaste, não apresentaram diferenças estatísticas entre si. O mesmo resultado foi encontrado para a altura das plantas.

Yamazoe et al. (1990), utilizando mudas de Euterpe edulis para enriquecimento de mata secundária, em três tipos de vegetação (capoeirinha, capoeira e capoeirão), constataram que há uma influência positiva do sombreamento da vegetação na porcentagem de sobrevivência da espécie, encontrando o melhor índice de sobrevivência (94,2\%) no capoeirão e o pior $(60,8 \%)$ na capoeirinha. Não houve diferença estatística com relação à altura das plantas e o número de folhas foi inferior no tratamento de capoeirinha.

Bovi et al. (1992) observaram respostas diferenciadas para emergência e sobrevivência de Euterpe edulis plantado em mata com limpeza de sub-bosque ( $50 \%$ de insolação) e em mata fechada, sem limpeza de subosque ( $25 \%$ de insolação), verificando maior emergência na área menos sombreada e maior sobrevivência na área mais sombreada.

Experimentos com sombreamento artificial, obtido através da utilização de sombrites, como o de Reis et al. (1987), sugerem que níveis elevados de sombreamento $(80 \%)$ provocam retardamento no crescimento de mudas de Euterpe edulis, sendo que os melhores índices de desenvolvimento foram obtidos nos sombreamentos de $20 \%, 40 \%$ e $60 \%$.

Nogueira Jr. et al. (1996), testando a interação entre sombreamento e umidade do solo, no estabelecimento de plântulas de Euterpe edulis, em condições de viveiro, constataram total mortalidade para pleno sol, desenvolvimento favorecido a $50 \%$ e $70 \%$ de sombreamento e alta mortalidade para solos saturados. No entanto, os resultados indicam haver uma interação positiva para menores níveis de sombreamento e solo saturado. 


\section{MATERIAL E MÉTODOS}

\subsection{Caracterização geral da área de estudo}

O estudo foi desenvolvido na Reserva Biológica de Paranapiacaba, unidade de conservação pertencente ao Instituto de Botânica da Secretaria de Estado do Meio Ambiente de São Paulo. A área possui 336 ha e está localizada no topo da Serra do Mar, no Município de Santo André, Estado de São Paulo, a $23^{\circ} 46^{\prime}$ de latitude sul e $46^{\circ} 18^{\prime}$ de longitude oeste (Figura 1 ).

Coutinho (1962) classificou a vegetação da Reserva Biológica de Paranapiacaba como Floresta Pluvial Tropical, sendo suas matas constituídas por uma vegetação arbórea secundária, relativamente densa, e por alguns testemunhos de mata primária nos locais de topografia mais acidentada. Muitas vezes a sinúsia arbórea estava representada por exemplares com mais de $30 \mathrm{~m}$ (Bombax wittrockianum, Alchornea triplinervia, Swartzia langsdorfii), mas as árvores de menor porte eram as mais freqüentes (Affonsea edwallii e Inga sessilis). A vegetação arbustiva foi descrita como pouco densa e a epifítica abundante e rica em espécies.

No entanto, a partir dos anos 60, a Reserva Biológica de Paranapiacaba passou a sofrer a influência dos poluentes atmosféricos provenientes do Complexo Industrial de Cubatão. Devido à sua posição topográfica, nos limites das escarpas da Serra do Mar, porções de sua vegetação passaram a receber grandes quantidades de poluentes, transportados ao topo da serra através dos ventos canalizados pelo vale do rio Mogi (Domingos et al., 1990). As faces mais 


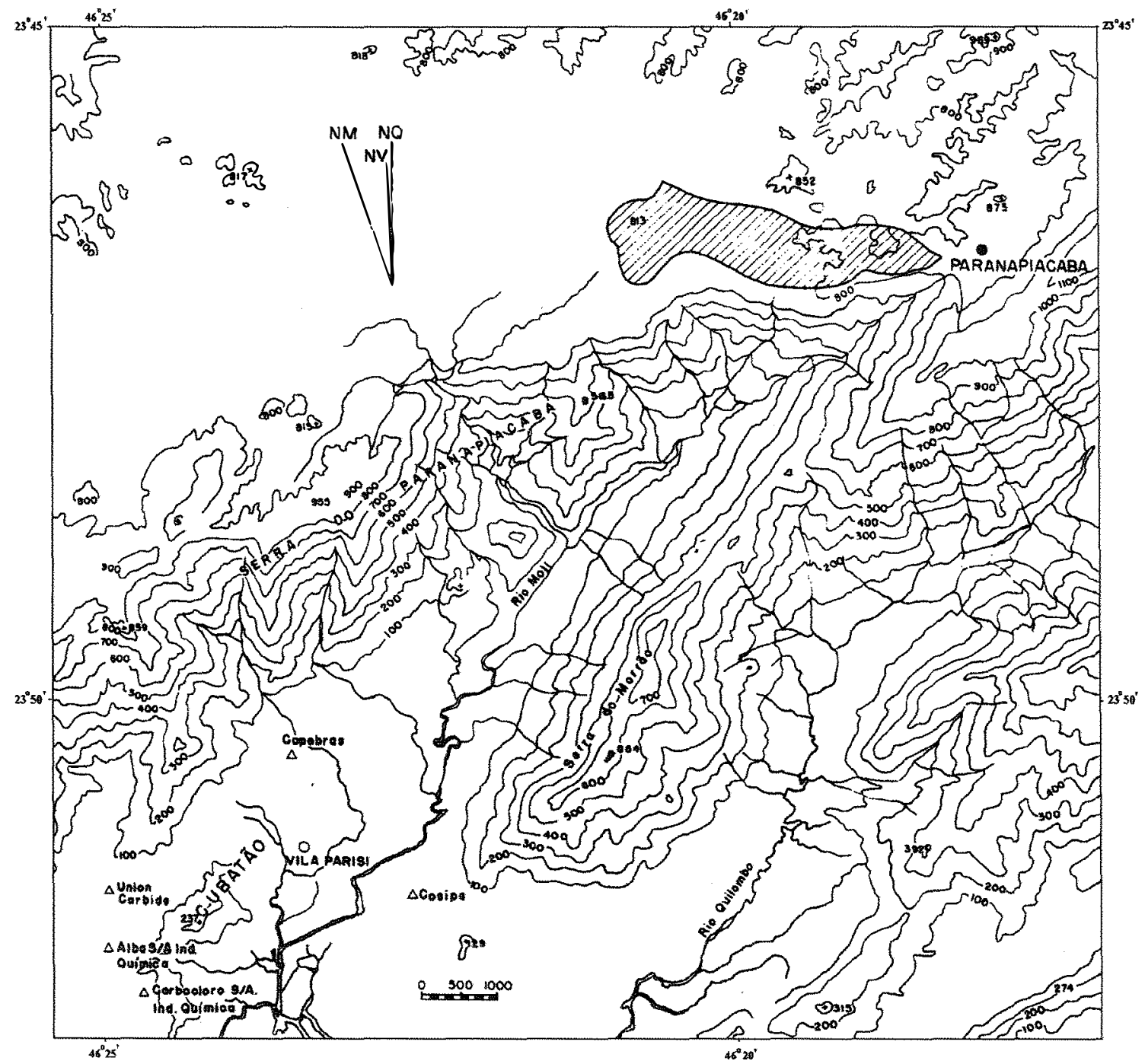

Figura 1 - Posição geográfica da Reserva Biológica de Paranapiacaba, no contexto da Serra do Mar e Baixada Santista ( YIIIC). Reproduzida a partir da Carta de Santos, IGGSP, 1972 (modificada por Domingos, 1987). 
expostas foram fortemente afetadas até, aproximadamente, 1980, sendo grande o número de árvores mortas encontradas nesses locais. Espécies pioneiras e secundárias iniciais das famílias de Melastomataceae e Euphorbiaceae passaram a ser predominantes. Algumas porções da floresta tem mostrado sinais de recuperação (Klumpp et al., 1997).

Outro fator que também contribuiu para a modificação da vegetação da Reserva Biológica de Paranapiacaba foi o extrativismo de palmito, que provocou a derrubada de inúmeros indivíduos de Euterpe edulis. Desde 1996, as invasões à área, visando à extração de palmito, estão sendo satisfatoriamente controladas.

O clima da região, de acordo com a classificação de Köppen e com base nas médias de temperatura e precipitação do Atlas Climático e Ecológico do Estado de São Paulo, organizado por Setzer (1966), é do tipo Cfb, que se caracteriza por ser úmido, com mais de $1.000 \mathrm{~mm}$ anuais, temperado, sem estação seca definida e temperaturas médias do mês mais frio inferior a $18^{\circ} \mathrm{C} \mathrm{e}$ do mês mais quente inferior a $22^{\circ} \mathrm{C}$.

Com relação à umidade relativa, durante todos os meses do ano observam-se valores de extrema umidade, muito próximos a $100 \%$. Mas, em certos dias do período de seca, estes valores podem ser inferiores a $50 \%$ (Coutinho,1962). Na região da Reserva Biológica de Paranapiacaba é comum a ocorrência de nevoeiro.

Funari et al. (1986), utilizando o método de Thornthwaite \& Mather, classificaram o clima da Reserva Biológica de Paranapiacaba como mesotérmico, superúmido, sem nenhum déficit de água e grande excesso no verão. Para o período considerado, 1945 a 1968, os autores constataram uma precipitação média anual de $3.381 \mathrm{~mm}$, sendo o ano mais chuvoso 1947, com um total de $4.727 \mathrm{~mm}$, e o ano mais seco 1963, com um total de $2.140 \mathrm{~mm}$.

No presente estudo, foi confeccionado o climadiagrama para a região (Figura 2), segundo a metodologia proposta por Walter (1986), cujos dados 


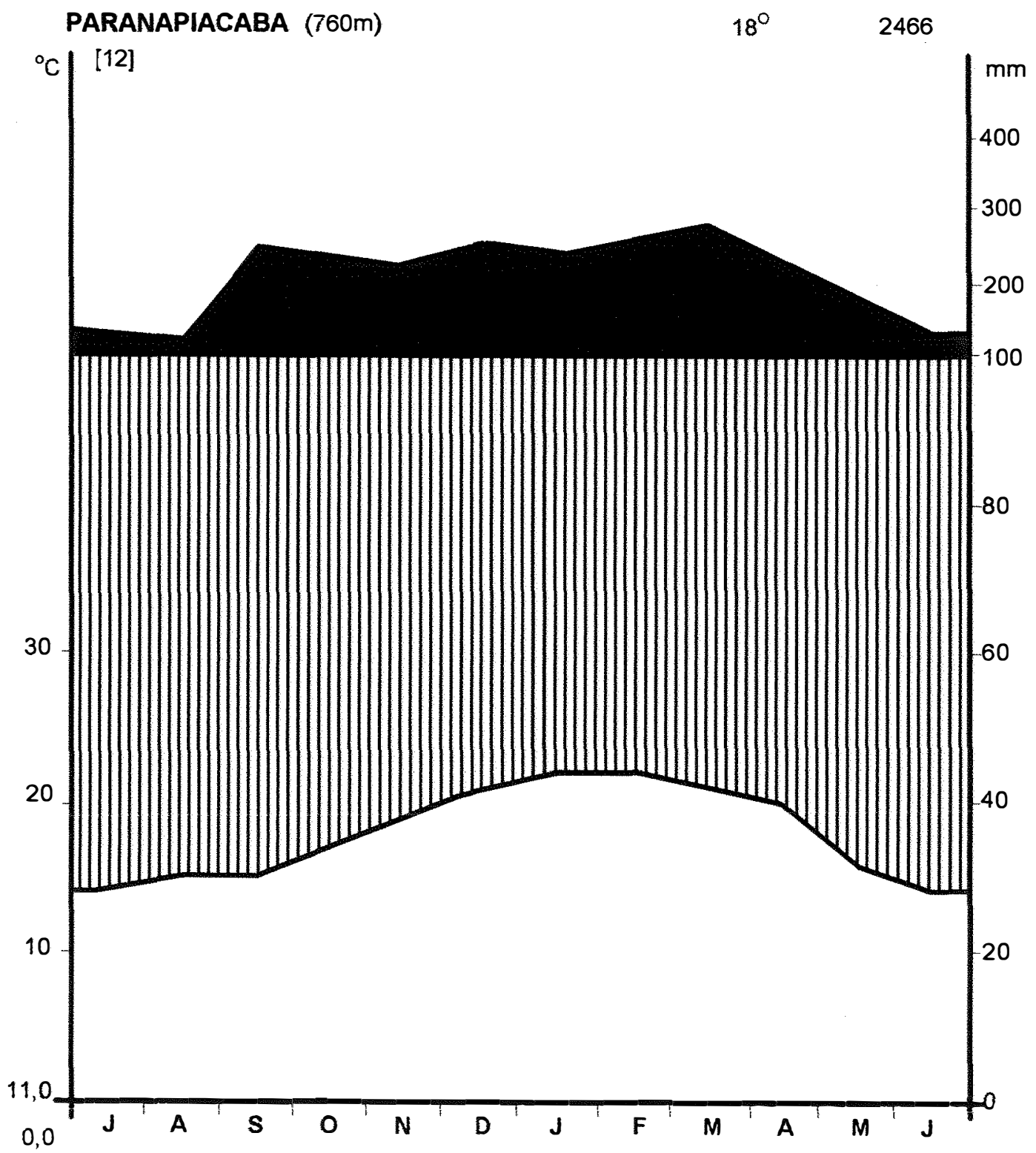

Figura 2 - Climadiagrama da região onde está situada a Reserva Biológica de Paranapiacaba, construído segundo a metodologia proposta por Walter (1986). 
referem-se aos anos de 1986 a 1997. No período considerado, constatou-se uma precipitação média anual de $2.431 \mathrm{~mm}$, sendo 1988 o ano mais chuvoso, com um total de $3.750 \mathrm{~mm}$, e 1990 o ano mais seco, com um total de $815 \mathrm{~mm}$. A temperatura média anual constatada foi de $18^{\circ} \mathrm{C}$, sendo o valor máximo registrado $35^{\circ} \mathrm{C}$, no mês de janeiro de 1995 e o valor mínimo registrado $0^{\circ} \mathrm{C}$, no mês de julho de 1990.

Quanto ao solo da Reserva Biológica de Paranapiacaba, segundo Lopes et al. (1993), o tipo dominante é o latossolo vermelho-amarelo, com influência hidromórfica nas camadas mais profundas (pseudogley), muito ácido, com valores de $\mathrm{pH}$ de 3,7 na superfície e 4,3 no subsolo.

\subsection{Avaliação da regeneração natural de Euterpe edulis}

Para avaliação da regeneração natural da espécie, foram selecionadas duas áreas na Reserva Biológica de Paranapiacaba: uma área perturbada pelo extrativismo predatório de palmito e outra área sem sinais de perturbações desta natureza. Em cada uma das áreas, foi estudada a estrutura local da população de Euterpe edulis.

\subsubsection{Características das áreas de estudo}

A área escolhida para o estudo da população não perturbada (ANP) está localizada próxima ao alojamento da unidade, a uma altitude de $840 \mathrm{~m}$, apresentando declividade muito acentuada (acima de 45\%). Segundo o testemunho de funcionários da reserva, esta área vem sendo mantida por muitos anos sem interferências causadas pelo extrativismo de palmito. Não há sinais de derrubada de Euterpe edulis, sendo grande a presença de indivíduos em diversos estádios de desenvolvimento. A cobertura vegetal apresenta-se 
visualmente em bom estado de conservação, no entanto, é possivel notar um número considerável de árvores de grande porte mortas em pé ou tombadas ao chão. 0 dossel apresenta-se de forma contínua e o estrato herbáceo é pouco desenvolvido (Figura 3).

A área escolhida para o estudo da população de Euterpe edulis perturbada por atividades extrativistas (AP) está localizada próxima à portaria da reserva, a uma altitude de $770 \mathrm{~m}$, apresentando topografia com baixa declividade. Com relação ao seu histórico, esta área vinha sendo mantida em estado razoável de conservação até o ano de 1992, quando grande parte dos indivíduos adultos de Euterpe edulis foi derrubada. Posteriormente a área foi mantida fora da interferência humana e vem se recuperando naturalmente. A cobertura vegetal encontra-se bastante alterada, com dossel descontínuo. A locomoção no interior da área é dificultada pela presença de um grande número de troncos de Euterpe edulis tombados ao chão e de um estrato herbáceo e arbustivo denso, muito desenvolvido, com a predominância de cipós e gramineas nos locais mais abertos (Figura 4).

As Tabelas 1 e 2 apresentam, respectivamente, os resultados das análises química e granulométrica do solo da área não perturbada pelo extrativismo (ANP) e da área perturbada pelo extrativismo (AP). Tais análises foram realizadas no Laboratório de Análises de Solos, do Departamento de Ciência do Solo, da Escola Superior de Agricultura "Luiz de Queiroz", da Universidade de São Paulo.

\subsubsection{Levantamento da estrutura da população}

Para o levantamento da estrutura da população de Euterpe edulis o método empregado foi o de parcelas, distribuídas de forma contínua ao longo das áreas de estudo (ANP e AP). Levantou-se, em cada um dos locais, uma área de $3.450 \mathrm{~m}^{2}$, que foi subdividida em 23 parcelas de $150 \mathrm{~m}^{2}(10 \times 15 \mathrm{~m})$. 

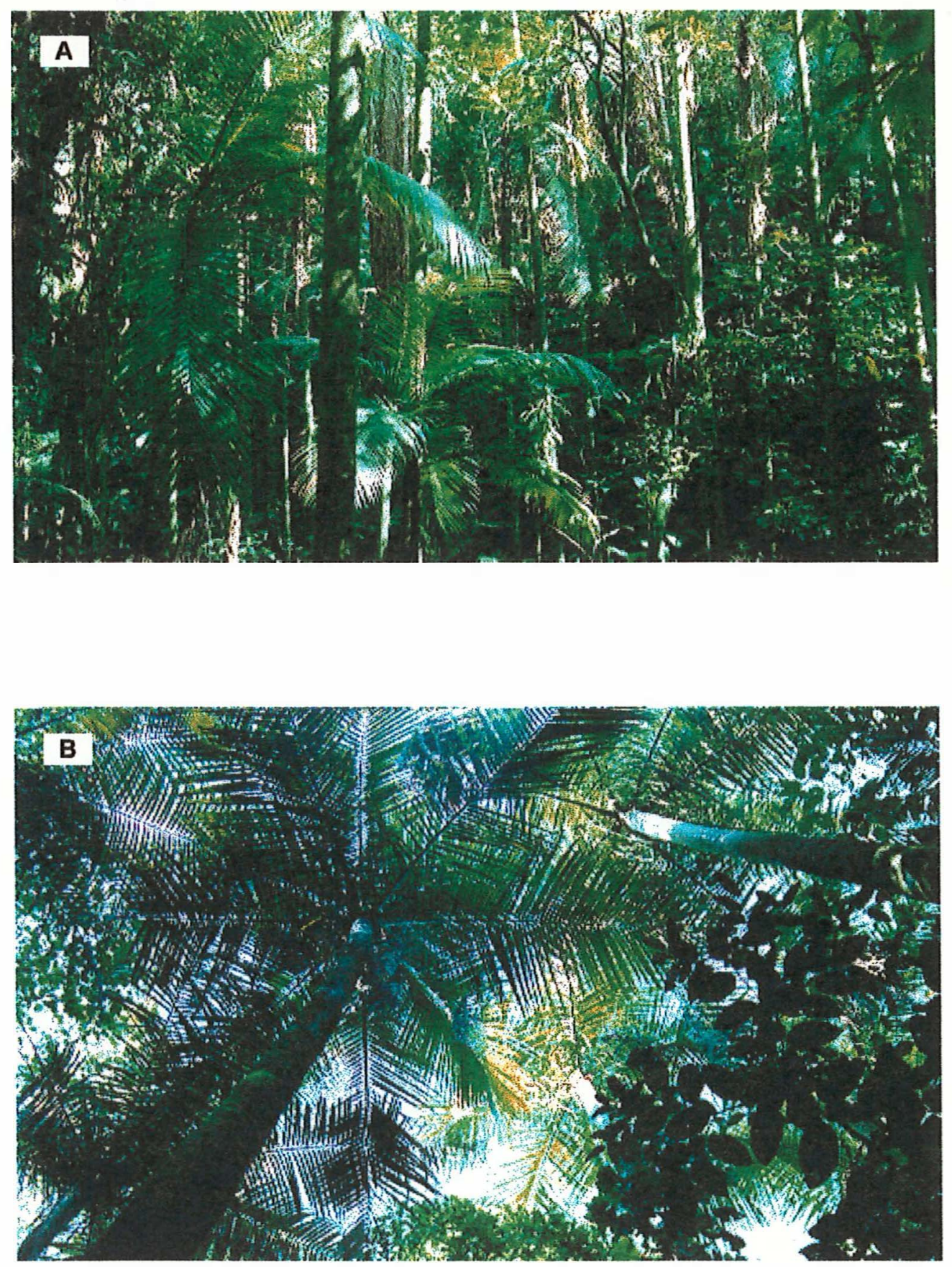

Figura 3 - Aspecto geral do interior da mata $(A)$ e do dossel (B) da área não perturbada pelo extrativismo de palmito (ANP), utilizada para o levantamento da estrutura da população de Euterpe edulis. 

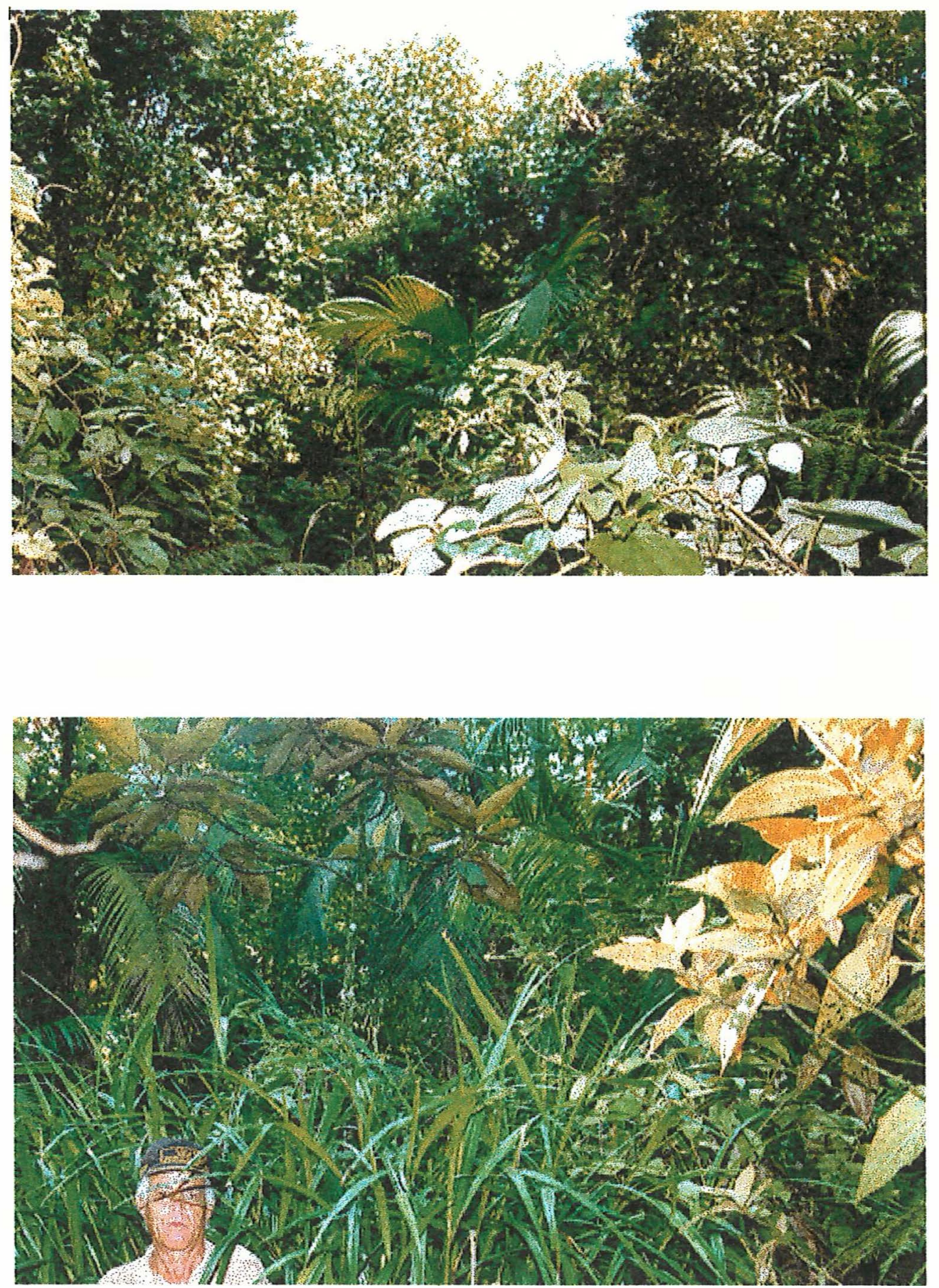

Figura 4 -Aspecto geral da área perturbada pelo extrativismo de palmito (AP), utilizada para o levantamento da estrutura da população alterada de Euterpe edulis. 
Tabela 1. Análise química do solo das áreas não perturbada (ANP) e perturbada (AP), nas profundidades de 0 a $10 \mathrm{~cm}$ e 10 a $20 \mathrm{~cm}$.

\begin{tabular}{|c|c|c|c|c|c|c|c|c|c|c|}
\hline \multirow[t]{2}{*}{ Área/profundidade } & $\mathrm{pH}$ & M.O & $P$ & K & $\mathrm{Ca}$ & $\mathrm{Mg}$ & $\mathrm{H}+\mathrm{Al}$ & $S B$ & $T$ & \multirow{2}{*}{$\begin{array}{l}\text { V } \\
\%\end{array}$} \\
\hline & $\mathrm{CaCl}_{2}$ & $g d^{-3}$ & $\mathrm{mg} \mathrm{dm}^{-3}$ & \multicolumn{6}{|c|}{ mmolc $\mathrm{dm}^{-3}$} & \\
\hline ANP / 0-10 & 3,1 & 84 & 25 & 1,6 & 10 & 2 & 313 & 13,6 & 326,6 & 4 \\
\hline ANP / 10-20 & 3,2 & 34 & 14 & 1,0 & 5 & 1 & 205 & 7,0 & 212,0 & 3 \\
\hline $\mathrm{AP} / 0-10$ & 3,1 & 67 & 19 & 1,7 & 16 & 2 & 205 & 19,7 & 224,7 & 9 \\
\hline AP / 10-20 & 3,3 & 23 & 6 & 0,9 & 4 & 1 & 88 & 5,9 & 93,9 & 6 \\
\hline
\end{tabular}

Tabela 2. Análise granulométrica do solo das áreas não perturbada (ANP) e perturbada (AP), nas profundidades de 0 a $10 \mathrm{~cm}$ e 10 a $20 \mathrm{~cm}$.

\begin{tabular}{ccccc}
\hline Área/profundidade & $\begin{array}{c}\text { Areia } \\
(\%)\end{array}$ & $\begin{array}{c}\text { Silte } \\
(\%)\end{array}$ & $\begin{array}{c}\text { Argila } \\
(\%)\end{array}$ & Classe de Textura \\
\hline ANP / 0-10 & 57 & 20 & 23 & média-arenosa \\
ANP / 10-20 & 56 & 20 & 24 & média-arenosa \\
AP / 0-10 & 63 & 25 & 12 & arenosa \\
AP / 10-20 & 68 & 20 & 12 & arenosa \\
\hline
\end{tabular}


A densidade do banco de plântulas, como foi chamado o estádio inicial de desenvolvimento, foi verificada em 23 sub-parcelas de $37,5 \mathrm{~m}^{2}(2,5 \times 15 \mathrm{~m})$, sendo cada uma instalada no interior da parcela de $150 \mathrm{~m}^{2}$. Foram incluidas as plântulas, propriamente ditas, como também indivíduos com altura inferior ou igual a $30 \mathrm{~cm}$, que já encontravam-se independentes das reservas das sementes.

Para o cálculo da densidade da espécie nos estádios superiores de desenvolvimento, foram contados todos os indivíduos presentes em cada parcela de $150 \mathrm{~m}^{2}$. Esses indivíduos foram separados em classes de altura, com intervalos de $1 \mathrm{~m}$, considerando-se a distância do colo da planta até o ponto de inserção das folhas. Em cada um dos indivíduos amostrados, com altura superior a 1,30 $\mathrm{m}$, foi medida também a circunferência do estipe à altura do peito (CAP), posteriormente transformada em diâmetro à altura do peito (DAP).

Em cada classe de altura dos palmiteiros, verificou-se a capacidade reprodutiva dos individuos amostrados, separando-os em jovens, adultos e "encapados". No estádio jovem, foram considerados todos os individuos com altura superior a $30 \mathrm{~cm}$ e que ainda não haviam atingido a fase reprodutiva. No estádio adulto, foram considerados os indivíduos com sinais evidentes de já terem se reproduzido, a saber: presença de inflorescências ou infrutescências sobre a planta, cicatrizes de inflorescências na parte superior do estipe, inflorescências caídas ou presença de um aglomerado de plântulas ao redor da planta observada (Reis, 1995). Para separação dos indivíduos "encapados", observou-se a presença de bainhas secas aderidas ao corpo da planta, impedindo o florescimento. Geralmente esses indivíduos apresentam-se cobertos por inúmeras trepadeiras (Figura 5).

Para avaliação da área basal de Euterpe edulis, em relação às outras espécies, consideraram-se todas as árvores com circunferência do caule, à altura do peito, igual ou superior a $30 \mathrm{~cm}(\mathrm{DAP} \geq 10 \mathrm{~cm})$. A área basal da 


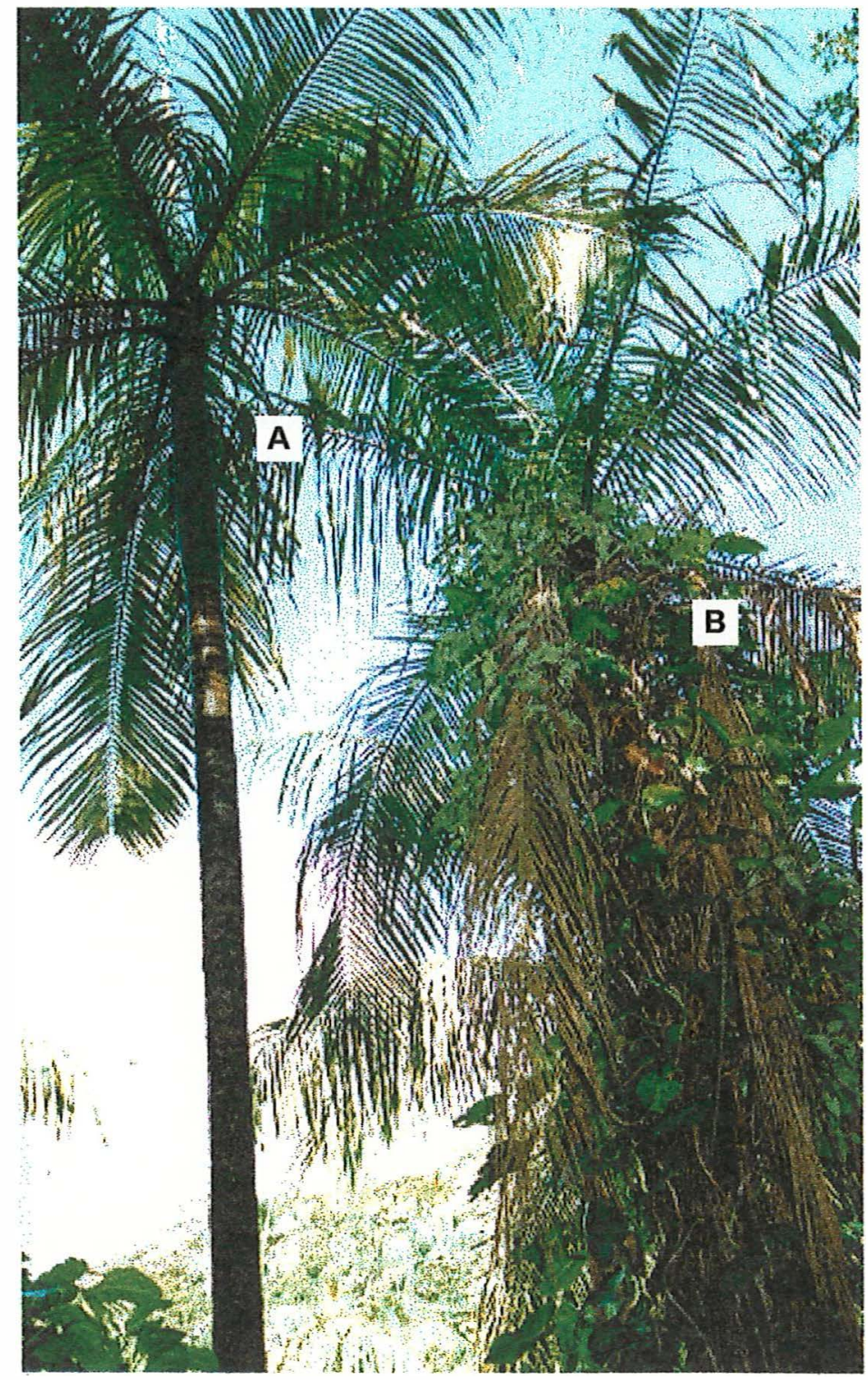

Figura 5 - Características de um indivíduo de Euterpe edulis "não encapado" (A) de um popularmente chamado de "macho" ou "encapado" (B). 
parcela foi calculada a partir da soma da área basal das árvores amostradas. A área basal de cada árvore foi calculada com a seguinte fórmula: $A B=\underline{\pi \cdot(D A P)^{2}}$

onde: $A B=$ área basal $\left(\mathrm{m}^{2}\right)$

$\pi \cong 3,1416$

$\mathrm{DAP}=$ diâmetro à altura do peito $(\mathrm{m})$

Para comparação das médias obtidas nas duas áreas de estudo, os dados de densidade foram submetidos ao teste estatístico de "Mann-Whitney", ao nivel de $5 \%$ de probabilidade, e os dados de diâmetro médio e área basal foram submetidos ao teste "t", também ao nivel de $5 \%$ de probabilidade.

\subsection{Avaliação do método de transplante de mudas de Euterpe edulis}

O experimento, para avaliação do método de transplante, consistiu em retirar as plântulas de Euterpe edulis, que encontravam-se aglomeradas ao redor da planta mãe, e transplantá-las, ainda no interior da mesma floresta, em locais com diferentes condições de luminosidade. Esses locais foram considerados como parcelas amostrais, onde foi medida a intensidade da radiação incidente e a sobrevivência e o crescimento das mudas transplantadas, ao longo de dezenove meses. Após este periodo, foram definidos três tratamentos de intensidade de radiação, formados pelo agrupamento das parcelas que apresentaram médias próximas.

\subsubsection{Características da área de estudo}

Para instalação das parcelas amostrais, foi utilizada uma terceira área $(\mathrm{AE})$, adjacente à área selecionada como "perturbada por atividades 
extrativistas" (AP), onde puderam ser encontradas várias condições de luminosidade no interior da floresta. A cobertura vegetal apresenta-se visualmente em bom estado de conservação, com dossel contínuo (exceto nos locais de clareiras naturais) e estratos herbáceo e arbustivo pouco densos. Os indivíduos adultos de Euterpe edulis não são freqüentes, mas podem ser avistados alguns indivíduos jovens e muitas plântulas.

As Tabelas 3 e 4 , apresentam, respectivamente, os resultados das análises química e granulométrica do solo da área utilizada para a instalação do experimento $(\mathrm{AE})$. Tais análises também foram realizadas no Laboratório de Análises de Solos, do Departamento de Ciência do Solo, da Escola Superior de Agricultura "Luiz de Queiroz", da Universidade de São Paulo.

Tabela 3. Análise química do solo da área utilizada para instalação do experimento $(A E)$, nas profundidades de 0 a $10 \mathrm{~cm} \mathrm{e} 10$ a $20 \mathrm{~cm}$.

\begin{tabular}{ccccccccccccc}
\hline \multirow{2}{*}{$\begin{array}{c}\text { Profundidade } \\
\mathrm{cm}\end{array}$} & $\mathrm{pH}$ & $\mathrm{M} . \mathrm{O}$ & $\mathrm{P}$ & $\mathrm{K}$ & $\mathrm{Ca}$ & $\mathrm{Mg}$ & $\mathrm{H}+\mathrm{Al}$ & $\mathrm{SB}$ & $\mathrm{T}$ & $\mathrm{V}$ \\
\cline { 5 - 7 } & $\mathrm{CaCl}_{2}$ & $\mathrm{~g} \mathrm{dm}^{-3}$ & $\mathrm{mg} \mathrm{dm}^{-3}$ & & & $\mathrm{mmolc} \mathrm{dm}^{-3}$ & & & \\
\hline $0-10$ & 3,3 & 48 & 16 & 1,5 & 12 & 4 & 150 & 17,5 & 167,5 & 10 \\
$10-20$ & 3,6 & 19 & 4 & 0,9 & 4 & 1 & 88 & 5,9 & 93,9 & 6 \\
\hline
\end{tabular}

Tabela 4. Análise granulométrica do solo da área utilizada para instalação do experimento (AE), nas profundidades de 0 a $10 \mathrm{~cm}$ e 10 a $20 \mathrm{~cm}$.

\begin{tabular}{ccccc}
\hline $\begin{array}{c}\text { Profundidade } \\
\mathrm{cm}\end{array}$ & $\begin{array}{c}\text { Areia } \\
(\%)\end{array}$ & $\begin{array}{c}\text { Silte } \\
(\%)\end{array}$ & $\begin{array}{c}\text { Argila } \\
(\%)\end{array}$ & Classe de Textura \\
$0-10$ & 70 & 18 & 12 & arenosa \\
$10-20$ & 72 & 16 & 12 & arenosa \\
\hline
\end{tabular}

Metodologia: método do densimetro

Classes de textura: até $14 \%$ - arenosa, 15 a 24\% - média arenosa, 25 a 34\% - média argilosa, 35 a 59\% - argilosa, $60 \%$ ou superior - muito argilosa. 


\subsubsection{Demarcação das parcelas}

As parcelas amostrais foram instaladas de forma sistemática, a partir de medições prévias de intensidade de radiação, realizadas em torno do meio dia, em várias condições no interior da floresta, desde pequenas clareiras até locais com pouca luminosidade, sob densa camada de árvores, arbustos e herbáceas.

O aparelho utilizado foi o espectro radiômetro fotômetro, marca LICOR, modelo $\mathrm{Ll}$-185B, com sensor quantum, que mede a intensidade da radiação fotossinteticamente ativa (PAR - 400 a $700 \mathrm{~nm}$ ), em $\mu \mathrm{mol} \cdot \mathrm{m}^{-2} . \mathrm{s}^{-1}$.

Ao final das leituras, foram demarcadas 9 parcelas amostrais de $16 \mathrm{~m}^{2}$ no interior da floresta, observando-se, em média, uma distância de $8 \mathrm{~m}$ entre uma parcela e outra.

\subsubsection{Seleção e plantio das mudas}

As mudas utilizadas no experimento foram retiradas ao pé de uma única matriz, sadia e de boa aparência, localizada no interior da floresta da Reserva Biológica de Paranapiacaba.

Foram selecionadas as mudas de melhor qualidade, provenientes da última frutificação, no estádio de plântula, com semente aderida, raiz principal ainda presente e primeira folha totalmente aberta (Figura 6), com altura e diâmetro semelhantes. As mudas foram retiradas da touceira ao pé da matriz no início da manhã do dia 11/12/96, transportadas com raiz nua em meio a Sphagnum umedecido e transplantadas antes do meio dia.

Em cada parcela, foram plantadas 10 mudas, escolhidas de forma aleatória, não havendo preocupação em manter o alinhamento de tais mudas no interior da parcela. 


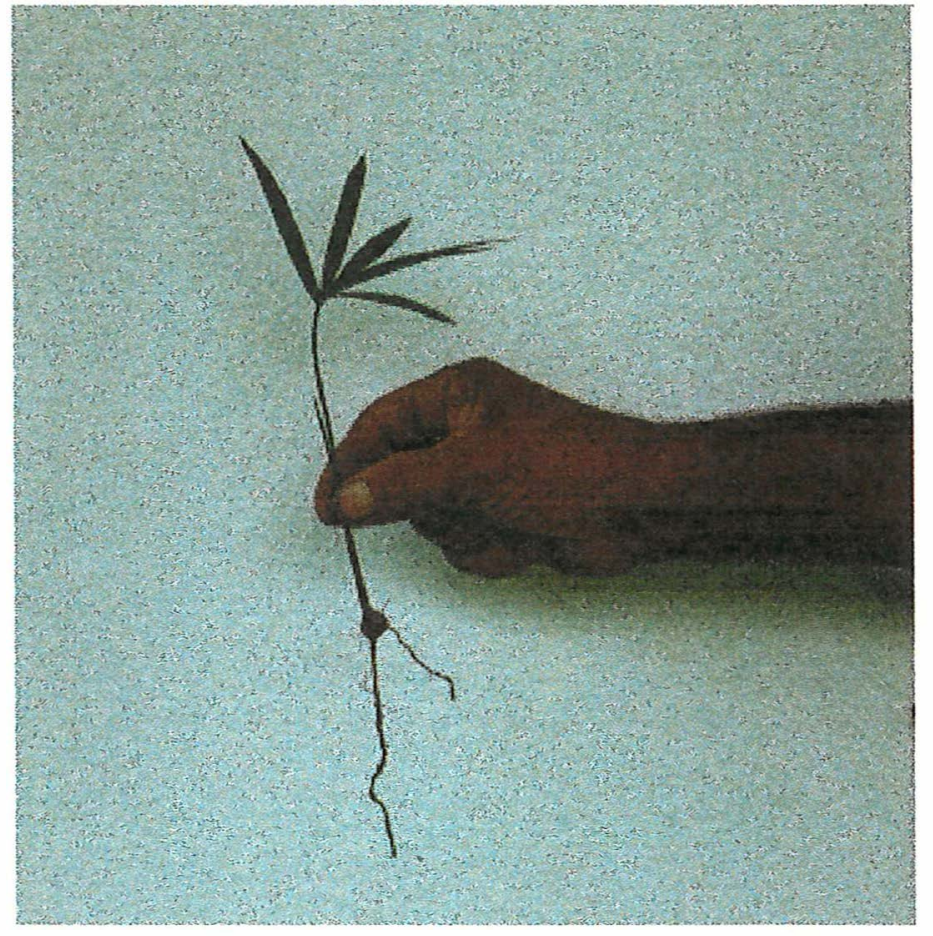

Figura 6 - Aspecto geral da muda de Euterpe edulis transplantada para as parcelas amostrais, com diferentes condições de luminosidade, no interior da floresta. 


\subsubsection{Parâmetros analisados}

Em intervalos de 60 dias, foram observados a sobrevivência e o crescimento das mudas. Foram anotados o número total de folhas, a altura, tomada do colo da planta até o limbo da folha mais alta, o diâmetro, tomado a $5 \mathrm{~cm}$ do colo da planta e as características da folha mais jovem, totalmente aberta: número de folíolos, comprimento e largura do folíolo central. Ao final do experimento, pelo método destrutivo, foram verificados o número e o comprimento das raizes e o peso seco atingido pela parte aérea e subterrânea.

As mudas permaneceram no campo durante dezenove meses. As medidas iniciais formam realizadas em dezembro de 1996 e as finais em julho de 1998.

\subsubsection{Acompanhamento da intensidade de radiação}

A intensidade da radiação foi medida tanto no interior da floresta, em cada uma das parcelas do experimento, como também fora da floresta, visando o acompanhamento da radiação total incidente. As leituras foram realizadas em 5 dias, distribuídos ao longo das estações do ano: 19/02/97 (verão), 27/05/97 (outono), 27/08/97 (inverno), 28/10/97 (primavera) e 05/02/98 (verão). Procurou-se realizar 4 leituras em cada dia, duas no período da manhã e duas no período da tarde, entre 10:00 e 14:00 horas, em dia de céu claro.

No interior da floresta, em cada uma das parcelas, as leituras foram tomadas à altura das folhas das mudas transplantadas. Procurou-se evitar a incidência direta de radiação no sensor, exceto nas parcelas mais abertas, quando esta era a condição geral.

A radiação total incidente foi medida em local aberto, longe da influência das copas das árvores, no início e no final de cada horário de leitura. 
A Tabela 5 apresenta as médias obtidas ao final do período de experimentação, estando as parcelas organizadas em ordem decrescente de intensidade de radiação. A parcela que apresentou maior média de intensidade de radiação foi a número $3, \operatorname{com} 254,91 \mu \mathrm{mol} \cdot \mathrm{m}^{-2} \cdot \mathrm{s}^{-1}$ (13,63 \% da radiação total). $O$ valor final encontrado nesta parcela foi muito superior aos valores encontrados em todas as outras parcelas. Este valor é justificado pelas condições da parcela 3, que foi instalada em uma pequena clareira, recém formada, cujas mudas de Euterpe edulis chegaram a receber radiação solar direta, o que não aconteceu com as mudas das demais parcelas. Em ordem decrescente de intensidade de radiação, as parcelas 1 e 2 ocupam o segundo lugar, com médias semelhantes, 26,08 e $22,45 \mu \mathrm{mol} \cdot \mathrm{m}^{-2} \cdot \mathrm{s}^{-1}(1,76 \%$ e $1,42 \%$ da radiação total). Estes locais foram sombreados apenas pelas copas das árvores. As parcelas 4, 5 e 7 apresentaram médias bem próximas, 13,75; 10,07 e $11,86 \mu \mathrm{mol} \cdot \mathrm{m}^{-2} \cdot \mathrm{s}^{-1}(0,94 \%, 0,79 \%$ e $0,66 \%$ da radiação total). De uma maneira geral, tais parcelas eram sombreadas pelas copas das árvores e por alguns arbustos. A parcela 6 , também com as mesmas características, apresentou uma média um pouco inferior às obtidas nas parcelas anteriores, $6,11 \mu \mathrm{mol} \cdot \mathrm{m}^{-2} \cdot \mathrm{s}^{-1}(0,38 \%$ da radiação total). As parcelas 8 e 9 foram as que receberam menor intensidade de radiação, por estarem bem protegidas, sombreadas por copas de árvores, arbustos e herbáceas de folhas largas, apresentando 3,70 e $3,73 \mu \mathrm{mol} \cdot \mathrm{m}^{-2} \cdot \mathrm{s}^{-1}(0,23 \%$ da radiação total).

Ao longo do período de experimentação, algumas parcelas apresentaram interferências. A parcela 4 apresentou problemas com relação à uniformidade na condição de iluminação à qual as mudas estiveram submetidas. As parcelas 5 e 7 apresentaram mudas com sinais de herbivoria nas folhas e grande mortalidade devido à ação de microrganismos, que provocaram o apodrecimento do colo de várias plantas, sendo que, na parcela 7 , houve $70 \%$ 
Tabela 5- Médias finais das leituras de intensidade de radiação (PAR) obtidas nas parcelas amostrais, onde foram transplantadas as mudas de Euterpe edulis. Período: fevereiro de 1997 a fevereiro de 1998.

\begin{tabular}{|c|c|c|c|c|}
\hline \multirow[t]{2}{*}{ Parcelas } & \multirow{2}{*}{$\begin{array}{c}\text { Características da } \\
\text { parcela }\end{array}$} & \multicolumn{3}{|c|}{ Intensidade de radiação (PAR) } \\
\hline & & $\begin{array}{l}\text { média absoluta } \\
\qquad\left(\mu \mathrm{mol} \cdot \mathrm{m}^{-2} \cdot \mathrm{s}^{-1}\right)\end{array}$ & $\begin{array}{l}\text { média relativa } \\
(\%)\end{array}$ & $\begin{array}{c}\text { coeficiente } \\
\text { de } \\
\text { variacão }\end{array}$ \\
\hline P3 & clareira recém formada & 254,91 & 13,63 & 0,297 \\
\hline $\mathrm{P} 1$ & $\begin{array}{c}\text { sub-bosque com sombreamento } \\
\text { proporcionado por copas de } \\
\text { árvores }\end{array}$ & 26,08 & 1,76 & 0,075 \\
\hline$P 2$ & $\begin{array}{c}\text { sub-bosque com sombreamento } \\
\text { proporcionado por copas de } \\
\text { árvores }\end{array}$ & 22,45 & 1,42 & 0,070 \\
\hline P4 & $\begin{array}{l}\text { sub-bosque com sombreamento } \\
\text { proporcionado por árvores e } \\
\text { arbustos }\end{array}$ & 13,75 & 0,94 & 0,292 \\
\hline P7 & $\begin{array}{c}\text { sub-bosque com sombreamento } \\
\text { proporcionado por árvores e } \\
\text { arbustos }\end{array}$ & 11,86 & 0,79 & 0,177 \\
\hline P5 & $\begin{array}{c}\text { sub-bosque com sombreamento } \\
\text { proporcionado por árvores e } \\
\text { arbustos }\end{array}$ & 10,07 & 0,68 & 0,147 \\
\hline P6 & $\begin{array}{c}\text { sub-bosque com sombreamento } \\
\text { proporcionado por árvores e } \\
\text { arbustos }\end{array}$ & 6,11 & 0,38 & 0,170 \\
\hline P8 & $\begin{array}{l}\text { sub-bosque com sombreamento } \\
\text { proporcionado por árvores, } \\
\text { arbustos e herbáceas }\end{array}$ & 3,70 & 0,23 & 0,196 \\
\hline P9 & $\begin{array}{l}\text { sub-bosque com sombreamento } \\
\text { proporcionado por árvores, } \\
\text { arbustos e herbáceas }\end{array}$ & 3,73 & 0,23 & 0,104 \\
\hline
\end{tabular}


de mortalidade aos 4 meses de experimentação. As observações feitas durante a amostragem de campo sugerem que a ação de microrganismos pode estar associada ao acúmulo de matéria orgânica ao pé da planta.

\subsubsection{Definição dos tratamentos}

A partir das médias de intensidade de radiação obtidas em cada parcela amostral, foram definidos três tratamentos para fins de avaliação da sobrevivência e crescimento das mudas de Euterpe edulis. Esses tratamentos foram chamados de RA (radiação alta), RM (radiação moderada) e RB (radiação baixa), sendo formados pelo agrupamento de parcelas que apresentaram médias com valores próximos (Tabela 6).

Tabela 6- Médias das leituras de intensidade de radiação (PAR) nos tratamentos RA (radiação alta), RM (radiação moderada) e RB (radiação baixa), onde foram transplantadas as mudas de Euterpe edulis. Período: fevereiro de 1997 a fevereiro de 1998.

Tratamento Característica Intensidade de radiação (PAR)

$$
\underset{\left(\mu \mathrm{mol} \cdot \mathrm{m}^{-2} \cdot \mathrm{s}^{-1}\right)}{\text { média }}
$$

média relativa

(\%) coeficiente

de variação

\begin{tabular}{ccccc}
\hline RA & $\begin{array}{c}\text { intensidade de } \\
\text { radiação alta }\end{array}$ & 254,91 & 13,63 & 0,297 \\
RM & $\begin{array}{c}\text { intensidade de } \\
\text { radiação } \\
\text { moderada }\end{array}$ & 24,26 & 1,57 & 0,107 \\
RB & $\begin{array}{c}\text { intensidade de } \\
\text { radiaçãa baixa }\end{array}$ & 3,71 & 0,23 & 0,163 \\
\hline
\end{tabular}


A parcela 3, por apresentar uma média bastante distinta das outras parcelas, $254,91 \mu \mathrm{mol} \cdot \mathrm{m}^{-2} \cdot \mathrm{s}^{-1}$, foi denominada de tratamento RA, sendo a intensidade de radiação considerada alta em relação aos demais. As parcelas 1 e 2, por apresentarem médias muito próximas, 26,08 e $22,45 \mu \mathrm{mol} \cdot \mathrm{m}^{-2} \cdot \mathrm{s}^{-1}$, porém distintas das demais parcelas, foram denominadas de tratamento RM, com intensidade moderada de radiação. Da mesma forma definiu-se o terceiro tratamento, RB, constituído pelas parcelas 8 e $9\left(3,70\right.$ e $\left.3,73 \mu \mathrm{mol} \cdot \mathrm{m}^{-2} . \mathrm{s}^{-1}\right)$, com intensidade de radiação baixa. As demais parcelas foram desconsideradas devido às interferências observadas ao longo do experimento, ou seja, ação de insetos e microrganismos.

As médias finais de sobrevivência e crescimento foram submetidas ao teste "F", para análise de variância, e ao teste "Tukey", para localização de diferenças significativas, ao nível de $5 \%$ de probabilidade. Cada muda constituiu 1 repetição.

\subsubsection{Umidade do solo}

Para caracterização do ambiente em cada parcela, foi medida a umidade do solo, em intervalos de 60 dias. Foram coletadas três amostras por parcela, até os $5 \mathrm{~cm}$ de profundidade. O método utilizado foi o de secagem em estufa, sendo as amostras úmidas pesadas, secas à $70^{\circ} \mathrm{C}$, e pesadas novamente para determinação da quantidade de água perdida.

A Figura 7 apresenta os valores médios de umidade do solo obtidos para os três tratamentos ( $R A, R M$ e $R B$ ), em cada dia de coleta. Em todas as parcelas dos tratamentos foram encontrados valores altos de umidade do solo. Este resultado se deve ao alto índice pluviométrico, com médias anuais acima de 3.000 mm (Funari et al. 1986), e à freqüente ocorrência de neblina na região da Reserva Biológica de Paranapiacaba. 


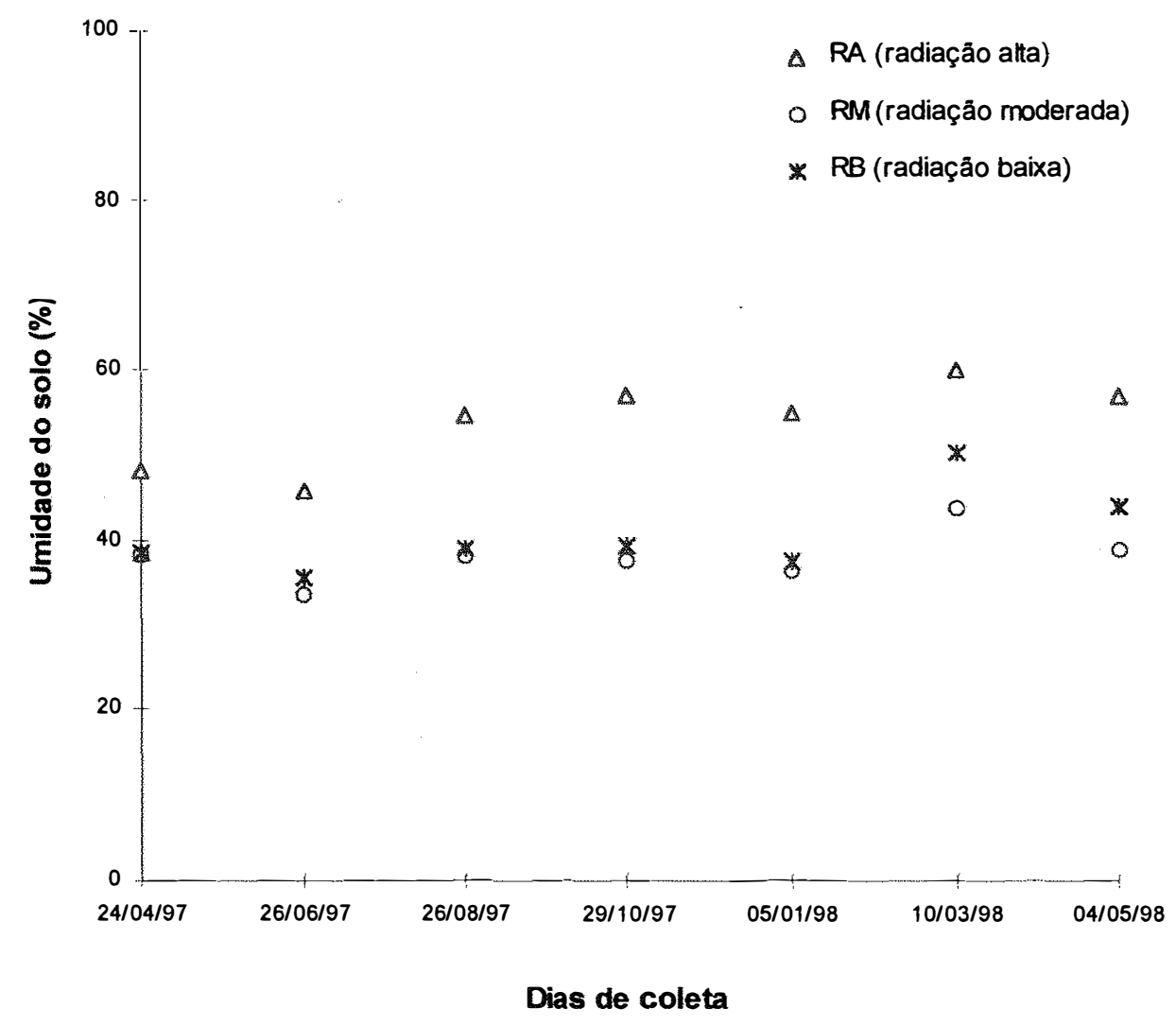

Figura 7 - Umidade do solo, de 0 a $5 \mathrm{~cm}$ de profundidade, nos tratamentos RA (radiação alta), RM (radiação moderada) e RB (radiação baixa). Período: abril de 1997 a maio de 1998. 
Foi observado que o solo no tratamento RA, em relação aos demais tratamentos, sempre esteve mais úmido, apresentando uma média de $54 \%$ de umidade. Este fato pode estar relacionado à vários fatores ligados à condição de pequena clareira deste tratamento, como precipitação abundante e freqüente, ocorrência diária de neblina, evaporação relativamente baixa, devido às médias amenas de temperatura e menor quantidade de superfície foliar evapotranspirante, em relação aos outros tratamentos, que possuem, além das mudas de Euterpe edulis, árvores, arbustos e herbáceas. Apesar do solo da parcela do tratamento RA apresentar umidade relativamente alta, não foram observadas condições de encharcamento, que pudessem prejudicar as mudas deste tratamento.

\subsubsection{Acompanhamento da temperatura e precipitação}

Ao longo do período de experimentação, foi acompanhado o andamento das temperaturas máxima e mínima e da precipitação (Figura 8), a partir de dados fornecidos pelo posto meteorológico da empresa MRS Logística, situado na Vila de Paranapiacaba, a uma altitude de $770 \mathrm{~m}$.

$\mathrm{O}$ mês mais quente foi fevereiro de 1997 , com uma média de $23^{\circ} \mathrm{C}$ e o mês mais frio foi junho de 1997 , com uma média de $10^{\circ} \mathrm{C}$. Os maiores valores de temperatura ocorreram em fevereiro e dezembro de $1997,32^{\circ} \mathrm{C}$ e $31^{\circ} \mathrm{C}$, respectivamente, e os menores valores ocorreram em junho e agosto de 1997 , $2^{\circ} \mathrm{C}$ e $3^{\circ} \mathrm{C}$, respectivamente.

Quanto à precipitação, os meses de novembro de 1997 e de fevereiro de 1998 foram os mais chuvosos, $501 \mathrm{~mm}$ e $528 \mathrm{~mm}$, respectivamente. O mês de julho de 1997 foi o mais seco, apresentando apenas $15,70 \mathrm{~mm}$ de chuva. No ano de 1997, a precipitação total atingiu $2.848 \mathrm{~mm}$. 

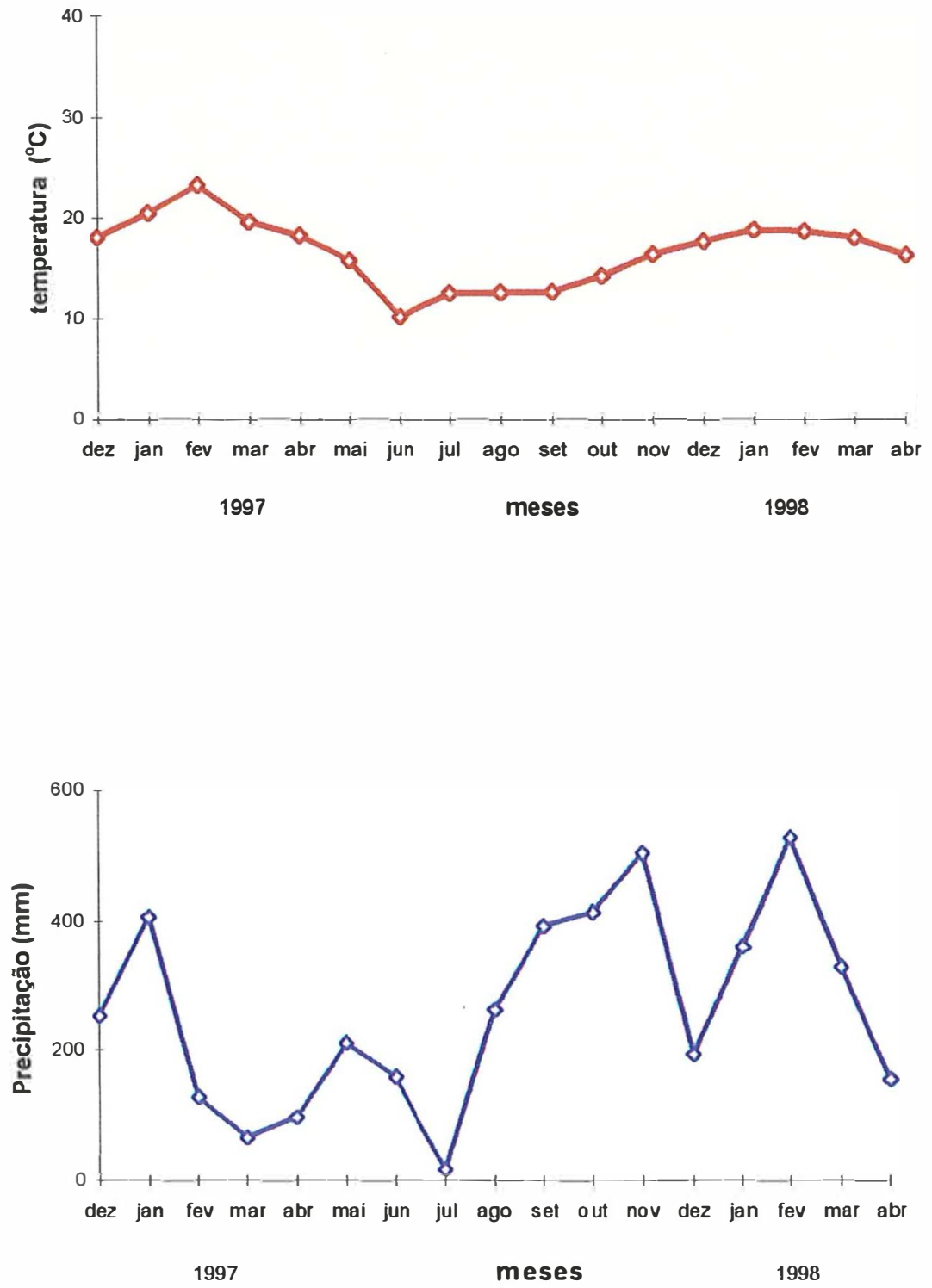

Figura 8 - Variação da temperatura média e precipitação total mensais da região de Paranapiacaba, Santo André, SP. Período: dezembro de 1996 a abril de 1998. 


\section{RESULTADOS E DISCUSSÃO}

\subsection{Avaliação da regeneração natural de Euterpe edulis}

\subsubsection{Densidade da espécie}

A Tabela 7 apresenta o número de individuos de Euterpe edulis e o diâmetro médio (DAP), verificados em cada classe de altura, separadas com intervalos de $1 \mathrm{~m}$, nas áreas não perturbada (ANP) e perturbada pelo extrativismo (AP).

$\mathrm{Na}$ área não perturbada pelo extrativismo (ANP), foram estimados 17.664 indivíduos no banco de plântulas $\left(5.120 / 1.000 \mathrm{~m}^{2}\right)$ e encontrados 441 jovens $\left(128 / 1.000 \mathrm{~m}^{2}\right)$ e 92 adultos $\left(27 / 1.000 \mathrm{~m}^{2}\right)$, enquanto que, na área perturbada (AP), foram estimados apenas 892 indivíduos no banco de plântulas $\left(259 / 1.000 \mathrm{~m}^{2}\right)$ e encontrados 405 jovens $\left(117 / 1.000 \mathrm{~m}^{2}\right)$ e somente 2 adultos $\left(0,58 / 1.000 \mathrm{~m}^{2}\right)$.

O número de individuos de Euterpe edulis encontrado no banco de plântulas da área perturbada, cerca de $5 \%$ do número encontrado em ANP, se deve à quase total eliminação dos indivíduos adultos de Euterpe edulis. Este fato reduziu drasticamente a produção de sementes no local e conseqüentemente a entrada de novos indivíduos no banco de plântulas, interrompendo o ciclo reprodutivo da população, ao longo dos últimos 5 anos. 
Tabela 7. Número de individuos de Euterpe edulis e diâmetro médio, por classe de altura, encontrados nas áreas não perturbada (ANP) e perturbada (AP). Área total levantada: $3.450 \mathrm{~m}^{2}$.

\begin{tabular}{|c|c|c|c|c|c|}
\hline \multirow[t]{2}{*}{ Classe } & \multirow[t]{2}{*}{ Intervalo de altura (m) } & \multicolumn{2}{|c|}{$N^{\circ}$ de indivíduos } & \multicolumn{2}{|c|}{ Diâmetro médio ${ }^{1}(\mathrm{~cm})$} \\
\hline & & ANP & AP & ANP & $A P$ \\
\hline Banco de plânt ul as & $<0,30$ & $17.664 a$ & 892 b & - & - \\
\hline 1 & 0,31 a 1,30 & $134 a$ & $121 \mathrm{a}$ & - & - \\
\hline 2 & 1,31 a 2,30 & $54 \mathrm{~b}$ & $77 a$ & $4,19 \mathrm{~B}$ & $4,89 \mathrm{~A}$ \\
\hline 3 & 2,31 a 3,30 & $52 a$ & 78 a & $4,78 \mathrm{~B}$ & $5,63 \mathrm{~A}$ \\
\hline 4 & 3,31 a 4,30 & $25 b$ & $63 a$ & $5,37 \mathrm{~B}$ & $6,90 \mathrm{~A}$ \\
\hline 5 & 4,31 a 5,30 & $40 \mathrm{a}$ & $48 a$ & $6,46 \mathrm{~B}$ & $7,86 \mathrm{~A}$ \\
\hline 6 & 5,31 a 6,30 & $35 a$ & $11 \mathrm{~b}$ & $8,70 \mathrm{~A}$ & $9,17 \mathrm{~A}$ \\
\hline 7 & 6,31 a 7,30 & $31 \mathrm{a}$ & $7 \mathrm{~b}$ & $11,39 \mathrm{~A}$ & $10,80 \mathrm{~A}$ \\
\hline 8 & 7,31 a 8,30 & $38 \mathrm{a}$ & $O b$ & 12,23 & - \\
\hline 9 & 8,31 a 9,30 & $38 \mathrm{a}$ & $\mathrm{Ob}$ & 13,56 & - \\
\hline 10 & 9,31 a 10,30 & $40 a$ & $1 \mathrm{~b}$ & $14,74 \mathrm{~B}$ & $19,00 \mathrm{~A}$ \\
\hline 11 & 10,31 a 11,30 & $24 a$ & $1 \mathrm{~b}$ & $14,99 \mathrm{~B}$ & $16,00 \mathrm{~A}$ \\
\hline 12 & 11,31 a 12,30 & $13 a$ & $\mathrm{Ob}$ & 15,77 & - \\
\hline 13 & 12,31 a 13,30 & $4 a$ & $0 \mathrm{a}$ & 17,77 & - \\
\hline 14 & 13,31 a 14,30 & $5 a$ & $0 \mathrm{a}$ & 16,40 & - \\
\hline Total de jovens & 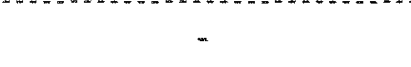 & $441 a$ & $405 a$ & 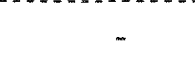 & - \\
\hline Total de adult os & - & $92 a$ & $2 b$ & - & - \\
\hline
\end{tabular}

- valores do número de indivíduos seguidos por letras minúsculas diferentes, na mesma linha, diferem entre si pelo teste "Mann Witney" $(p<0,05)$

- valores de DAP médio seguidos por letras maiúsculas diferentes, na mesma linha, diferem entre si pelo teste " $t$ " $(p<0,05)$ 
Além da baixa densidade, a má distribuição dos indivíduos do banco de plântulas poderá dificultar ainda mais a recuperação da área, podendo trazer sérias conseqüências para a regeneração da espécie. Grande parte dos indivíduos encontrava-se ao redor de apenas duas palmeiras adultas, sendo que uma delas já apresentava sinais de senescência. No entanto, foram encontrados, também, alguns cachos inteiros, com frutos, distantes dessas plantas, que provavelmente foram levados por animais. Este fato reforça a importância das interações existentes entre Euterpe edulis e a fauna, verificadas por Reis (1995), e que, neste caso, vêm contribuindo para o repovoamento da área perturbada.

Nos estádios de desenvolvimento seguintes, observa-se que, da classe 2 à classe 5 de altura, a densidade dos indivíduos é maior na área perturbada pelo extrativismo, bem como o diâmetro médio por classe de altura (Tabela 7). Estes resultados podem estar relacionados à maior entrada de luz no interior da floresta, como conseqüência da grande derrubada de palmeiras que ocorreu no local. Segundo Reis et al. (1987), em florestas clímax, onde há um maior sombreamento, o crescimento inicial de Euterpe edulis tende a ser retardado de modo a manter o equilíbrio da população. Os indivíduos do banco de plântulas podem ficar neste estádio por vários anos, até que ocorram condições de ambiente favoráveis ao seu crescimento (Butgnol, 1992). Sendo assim, em uma floresta menos adensada, o crescimento pode ocorrer de forma mais rápida. Hering (1994) comenta que, em uma área de Mata Atlântica utilizada para a exploração sustentada do palmiteiro, em Blumenau, SC., o número de plântulas e plantas jovens de Euterpe edulis, dobrou em 12 anos, como conseqüência do aumento da luminosidade do sítio a partir das práticas de manejo adotadas e da retirada das palmeiras em ponto de corte. Sendo assim, o fato de $E$. edulis, em condições naturais, possuir um banco de plântulas numeroso, pode ser entendido como uma vantagem para esta espécie, pois, no caso de uma 
perturbação no ecossistema, maior número de indivíduos poderão ser recrutados, acelerando, assim, a recuperação da estrutura da população.

Quanto ao diâmetro médio por classe de altura, são nítidas as diferenças encontradas entre as duas áreas de estudo, sendo significativamente maiores os diâmetros dos indivíduos amostrados na área perturbada pelo extrativismo (Tabela 7 e Figura 9). Butgnol (1992), utilizando Euterpe edulis como modelo para a elaboração de uma escala de desenvolvimento de palmeiras de folhas pinadas, constatou que o engrossamento do estipe tem na luminosidade seu fator mais importante, pois ocorre quando a altura da planta permite maior interceptação da radiação no estrato médio da floresta. Bovi et al. (1992) verificaram que, em mata nativa, com limpeza de sub-bosque, há maior incremento no diâmetro de mudas de Euterpe edulis, do que em mata nativa sem nenhuma intervenção prévia.

\subsubsection{Capacidade reprodutiva da população de palmiteiros}

A Figura 10 apresenta a proporção de indivíduos jovens, adultos e "encapados", em cada classe de altura, a partir da classe 2 (1,30 a 2,30 m). Os indivíduos pertencentes à classe $1(0,31$ a 1,30 m) não foram incluídos na Figura, pois neste intervalo de altura não foi possível distinguir indivíduos "encapados" de "não encapados".

Da classe 2 à classe 5 de altura, apesar de haver maior número de indivíduos na área perturbada pelo extrativismo, $81,5 \%$ dos indivíduos amostrados foram inseridos na categoria "encapados", enquanto que, na área não perturbada, este valor correspondeu a apenas $17,5 \%$. Struffaldi - De Vuono et al. (1992), estudando a estrutura das populações dos componentes arbóreo e arbustivo, em área afetada pela poluição, na Reserva Biológica de Paranapiacaba, observaram que de um total de 85 indivíduos de Euterpe edulis, em 43 o palmito apresentava-se encapado, ou seja, $50,6 \%$ do total amostrado. 


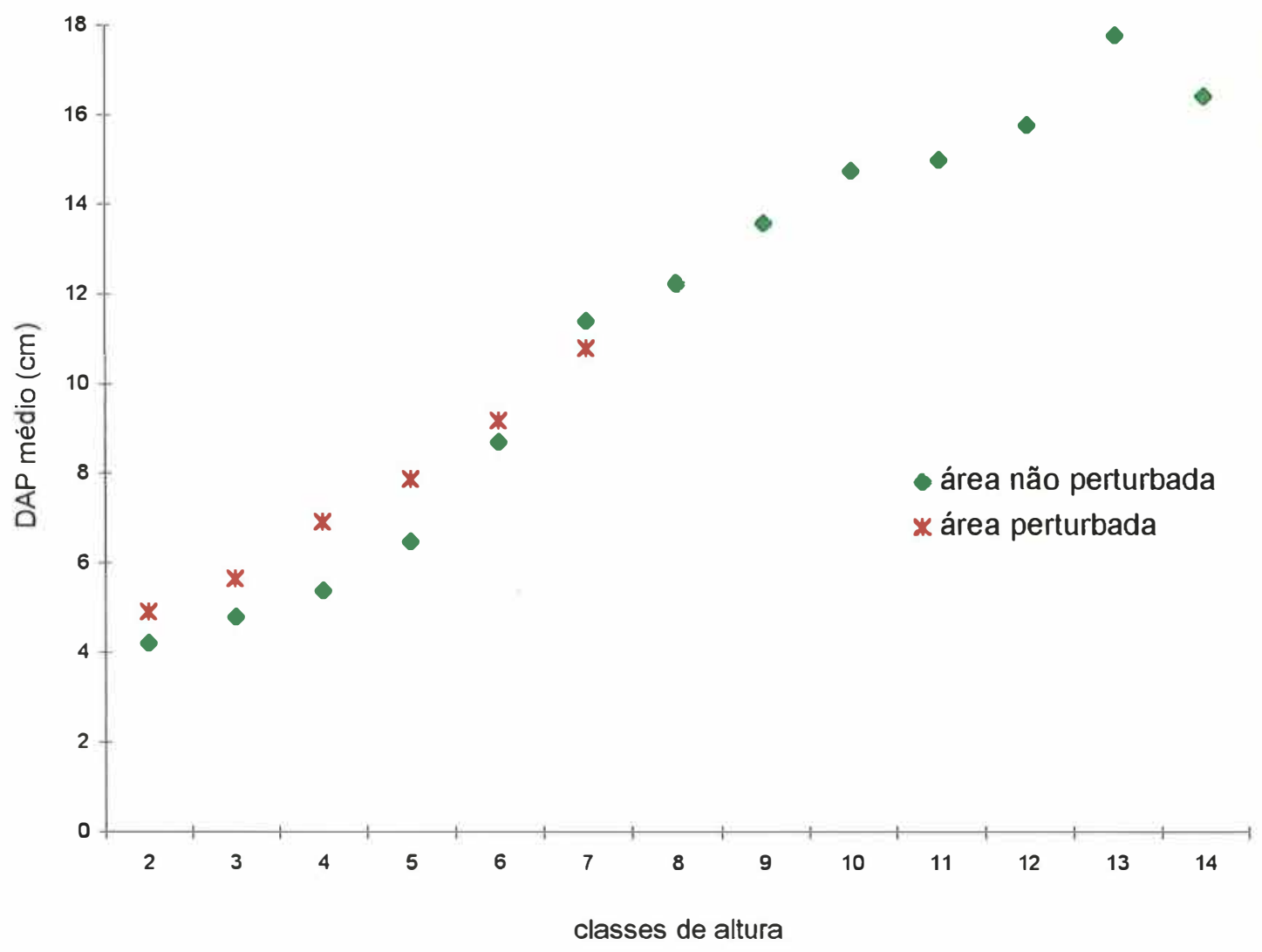

Figura 9 - Comparação entre os diâmetros médios (DAP), calculados por classe de altura (a partir de 1,30 m, com intervalos de $1 \mathrm{~m}$ ), dos individuos amostrados nas áreas não perturbada e perturbada. 

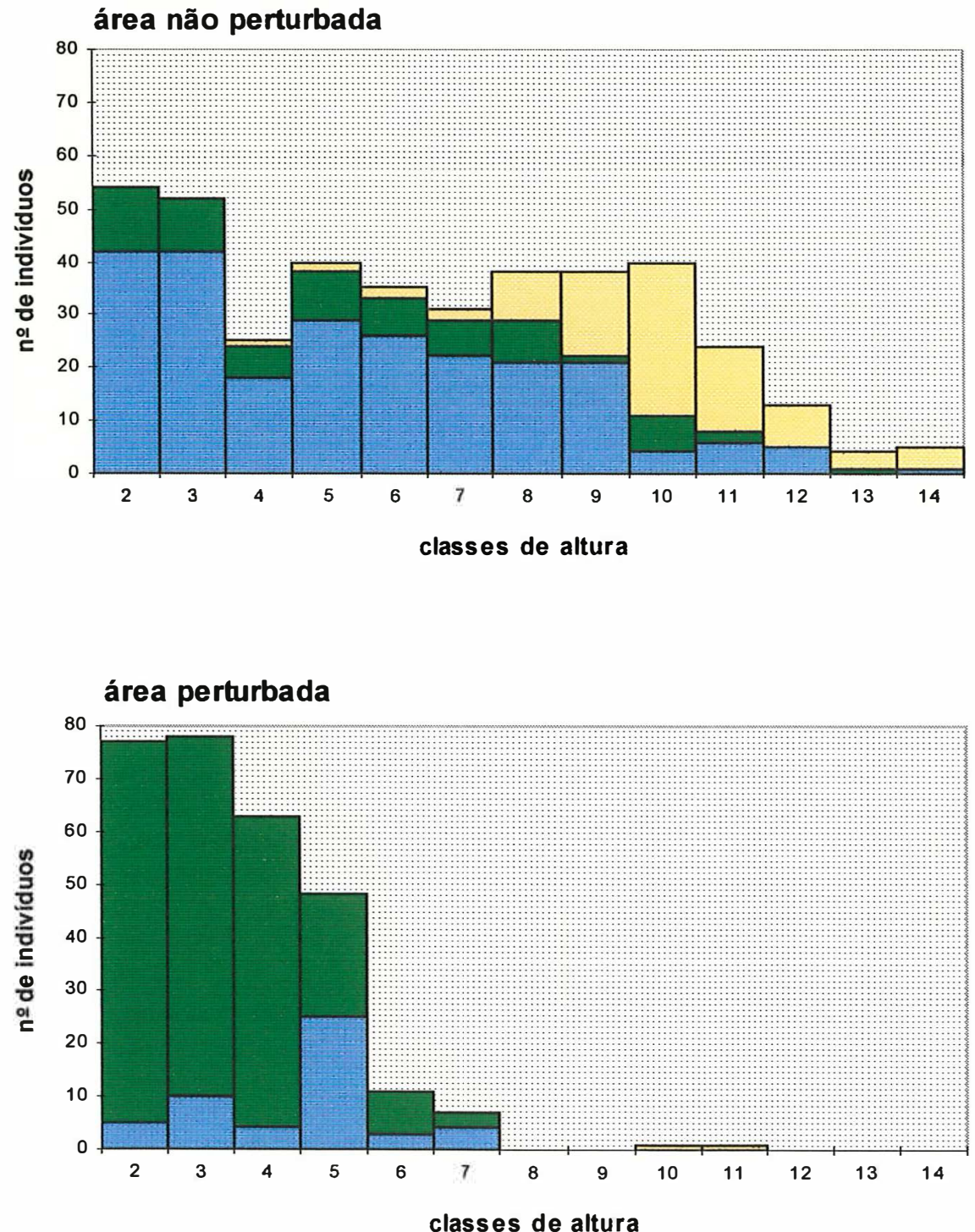

jovens

"encapados"

adultos

Figura 10 -Comparação entre a proporção de indivíduos jovens, "encapados" e adultos de Euterpe edulis, separados por classe de altura (a partir de 1,30 $\mathrm{m}$, com intervalos de $1 \mathrm{~m})$, existentes nas áreas não perturbada e perturbada. Área total levantada: $3.450 \mathrm{~m}^{2}$. 
Os indivíduos "encapados" representam um exemplo concreto de impedimento para a reprodução em uma população de palmiteiros, pois, as bainhas secas das folhas, que ficam aderidas ao corpo desses indivíduos, impedem que a inflorescência fique exposta aos polinizadores (Reis, 1995).

A pesquisadora Simey Thury Vieira Fisch, do Departamento de Biologia da Universidade de Taubaté (SP), suspeita de que o aparecimento de indivíduos "encapados" na população de palmiteiros esteja relacionado à maior umidade do solo e que o impedimento à reprodução seja temporário, pois foi observado o destacamento das bainhas secas em alguns indivíduos que atingiram a altura aproximada de $10 \mathrm{~m}$. Nesse sentido, a umidade do solo pode estar contribuindo para elevar a proporção de indivíduos "encapados" na área perturbada, pois o local encontra-se próximo aos córregos da reserva biológica. No entanto, o valor encontrado foi muito superior ao da área não perturbada, sugerindo que as alterações ambientais, provocadas pelo extrativismo, também possam estar contribuindo para esta alta proporção.

Se o impedimento à reprodução for temporário, a área estudada poderá recuperar-se naturalmente, pois existe um grande número de indivíduos jovens, "encapados" e "não encapados", potencialmente capazes de contribuir para a regeneração da espécie no futuro. Mas se o impedimento à reprodução for definitivo, a recuperação da área perturbada será mais uma vez prejudicada, pois a grande maioria dos indivíduos jovens presentes no local não poderá contribuir com descendentes.

Com relação à amostragem dos indivíduos adultos, nos $3.450 \mathrm{~m}^{2}$ da área não perturbada pelo extrativismo (ANP) foram encontrados 92 indivíduos adultos, cerca de $28 / 1.000 \mathrm{~m}^{2}$.

Fantini et al. (1993) realizando um levantamento em uma área de 1,8 ha, selecionada para coleta de sementes de Euterpe edulis, no Vale do Rio Ribeira, $\mathrm{SP}$, constataram a presença de 472 plantas matrizes $\left(26 / 1.000 \mathrm{~m}^{2}\right)$, valor bem próximo ao encontrado no presente estudo. Os autores caracterizaram como 
muito alta a densidade encontrada, comparando este valor com outro levantamento, realizado pelos mesmos autores, em uma área de 140 ha, no mesmo vale e com a mesma tipologia florestal $\left(10,3 / 1.000 \mathrm{~m}^{2}\right)$. Um número muito inferior foi verificado por Reis (1995), em uma área de 5,4 ha de uma Floresta Ombrófila Densa Montana, em Santa Catarina: 305 plantas de Euterpe edulis no estádio de adulto $\left(5,6 / 1.000 \mathrm{~m}^{2}\right)$.

Para se comparar estes valores, deve ser ressaltado que o tamanho das áreas amostradas e o objetivo de cada trabalho podem ter influenciado nos resultados encontrados. As maiores densidades foram obtidas em áreas pequenas e de concentração de palmiteiros: 0,35 ha na Reserva Biológica de Paranapiacaba e 1,8 ha na área selecionada para coleta de sementes no Vale do Ribeira. As menores densidades foram encontradas nos levantamentos com área de amostragem maior, 140 ha e 5,4 ha, nas quais ocorre uma maior variação ambiental e conseqüentemente uma maior variação da distribuição dos palmiteiros. Reis (1995) verificou que declives acentuados, contrastando picos de morro e fundos de vale, caracterizaram, em sua área de estudo, uma variação ambiental que refletiu diretamente sobre a população local de palmiteiros, sendo constatados, nesses locais, prioritariamente a presença de indivíduos que ainda não haviam atingido a fase reprodutiva.

Analisando novamente a Figura 10, verifica-se que, na área não perturbada pelo extrativismo (ANP), os indivíduos adultos passaram a ser representativos a partir da classe 8 de altura (acima de 7,30 m), no entanto, também foram encontrados indivíduos baixos, com altura ao redor de $4 \mathrm{~m}$ (classe 4), já no estádio adulto. Na área perturbada pelo extrativismo (AP), classes superiores à classe 8 são praticamente inexistentes, sendo que foram encontrados apenas 2 indivíduos adultos em toda a área de amostragem $\left(0,58 / 1.000 \mathrm{~m}^{2}\right)$.

Para a extração do palmito, a palmeira é cortada a uma altura aproximada de $1,5 \mathrm{~m}$ do solo. Sendo assim, foi possível amostrar o DAP de 
grande parte das palmeiras cortadas, pois seus troncos ainda permaneciam em pé. A Figura 11 apresenta o número de indivíduos amostrados nas duas áreas de estudo, separados por diâmetro (DAP). No gráfico da área perturbada pelo extrativismo, foi feita uma projeção de parte dos indivíduos que foram derrubados durante as atividades extrativistas.

Fantini et al. (1993) detectaram que as plantas matrizes de palmiteiros tendem a se concentrar entre os diâmetros (DAP) de 10 a $14 \mathrm{~cm}$, no entanto, foram encontradas, no estudo realizado, plantas em fase de frutificação desde $7,8 \mathrm{~cm}$ até $17,3 \mathrm{~cm}$ de DAP. Os gráficos da Figura 11 , revelam que a derrubada dos indivíduos coincide com os diâmetros onde se concentram grande parte dos indivíduos em período reprodutivo. Sendo assim, o extrativismo provoca a eliminação dos indivíduos responsáveis pela regeneração da espécie, e, por isso, foi encontrado um número muito baixo de indivíduos no banco de plântulas da área afetada pelo extrativismo.

A legislação no Estado de São Paulo, que regulamenta a exploração de Euterpe edulis em áreas de manejo de rendimento sustentado, exige a manutenção de, no mínimo, 50 palmiteiros por hectare em fase de frutificação, distribuídos o mais homogeneamente possivel na área a ser explorada (São Paulo, 1992). Na área perturbada pelo extrativismo, na Reserva Biológica de Paranapiacaba, foram amostrados apenas 2 indivíduos em fase de frutificação (5,8 palmiteiros por hectare), um valor bastante inferior ao número recomendado.

Segundo Butgnol (1992), a fase da reprodução em Euterpe edulis pode ser adiantada pela maior exposição aos raios solares, sendo que plantas mais ensolaradas não apresentam alternância tão acentuada no florescimento e produção de frutos. Reis (1995), a partir de observações localizadas, sugere também que o recrutamento para a fase reprodutiva pode estar associado à maior luminosidade do sítio. Ao longo de seu trabalho, o autor observou que algumas plantas que passaram do estádio imaturo para adulto, encontravam-se 


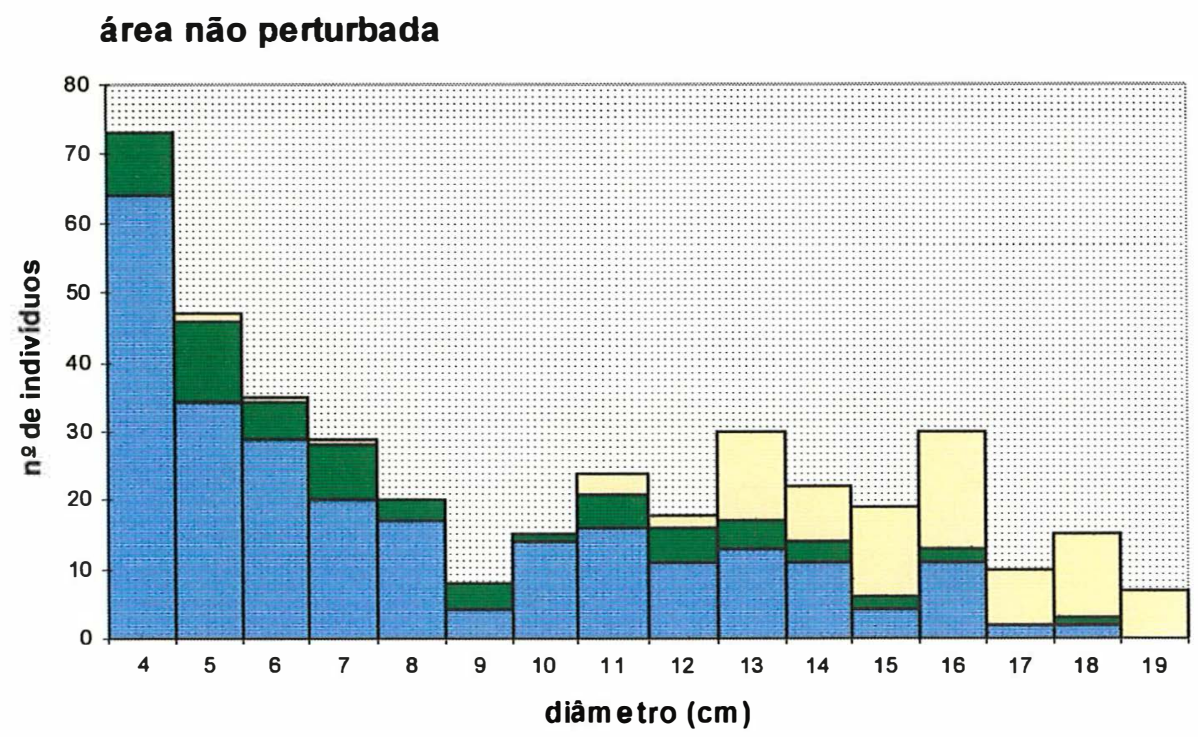

área perturbada

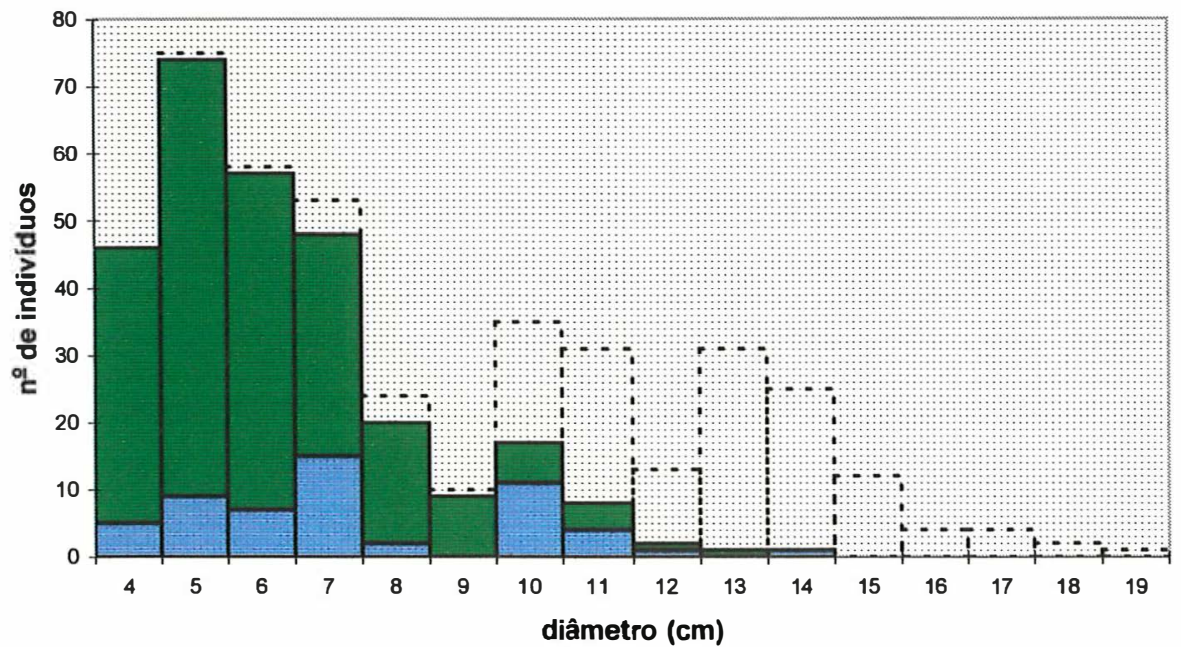

jovens $\square$ "encapados" $\square$ adultos $\quad \vdots \cdots \vdots$ cortados

Figura 11 - Número de indivíduos de Euterpe edulis, separados por DAP (diâmetro à altura do peito), existentes nas áreas não perturbada e perturbada. Área total levantada: $3.450 \mathrm{~m}^{2}$. 
ao redor de clareiras naturais. O aumento do número de inflorescências por planta também mostrou-se relacionado com o aumento da luminosidade do sítio. O mesmo foi constatado por Fantini et al. (1993).

Se o adiantamento da fase reprodutiva em Euterpe edulis estiver realmente associada à maior luminosidade do sítio, os indivíduos jovens da área perturbada pelo extrativismo talvez possam frutificar e produzir descendentes em tempo mais curto, acelerando a recuperação da espécie nesta área.

Observa-se, ainda, uma queda no número de indivíduos com 8,9 e 10 $\mathrm{cm}$ de DAP, em ambas as populações de palmiteiros (Figura 11). Em julho de 1990, ocorreu uma forte geada na região da Reserva Biológica de Paranapiacaba, quando os termômetros chegaram a registrar $0^{\circ} \mathrm{C}$. Neste período, foi observada a morte de várias palmeiras, o que provavelmente reduziu a produção de sementes no local. Outro fator que pode ter contribuído para esta mortalidade foi a poluição atmosférica proveniente do Complexo de Cubatão, que, ao longo de vários anos, vem afetando porções da vegetação da Reserva (Domingos et al., 1990).

\subsection{3 Área basal}

Os valores de área basal apresentados pelos indivíduos de Euterpe edulis e pelas outras espécies, encontrados em $3.450 \mathrm{~m}^{2}$ das áreas não perturbada (ANP) e perturbada pelo extrativismo (AP), estão contidos na Tabela 8

Verifica-se que na área não perturbada pelo extrativismo (ANP) Euterpe edulis apresentou uma área basal de $3,02 \mathrm{~m}^{2}\left(0,87 / 1.000 \mathrm{~m}^{2}\right)$, o que representou 39\% da área basal total, considerando-se a comunidade arbórea como um todo. Este valor, na área perturbada pelo extrativismo (AP), foi reduzido para $0,32 \mathrm{~m}^{2}\left(0,09 / 1.000 \mathrm{~m}^{2}\right), 5 \%$ da área basal total. 
Tabela 8. Área basal de Euterpe edulis e da soma das outras espécies encontradas nas áreas não perturbada (ANP) e perturbada (AP), considerando-se indivíduos com DAP $\geq 10 \mathrm{~cm}$. Área total levantada: $3.450 \mathrm{~m}^{2}$.

Espécies

Área basal $\left(\mathrm{m}^{2}\right)$

Número de indivíduos

$\begin{array}{llll}\text { ANP } & \text { AP } & \text { ANP }\end{array}$

Euterpe edulis

3,02 a

$0,32 \mathrm{~b}$

$190 \mathrm{~A}$

$32 \mathrm{~B}$

Outras espécies

$4,70 \mathrm{~b}$

6,27 a

203 B

$260 \mathrm{~A}$

Área basal total

$7,72 \mathrm{a}$

6,59 a

$393 \mathrm{~A}$

292 B

- valores de área basal seguidos por letras minúsculas diferentes, na mesma linha, diferem entre si pelo teste " $t$ " ( $p<0,05$ )

- valores do número de individuos seguidos por letras maiúsculas diferentes, na mesma linha, diferem entre si pelo teste "Mann Witney" ( $p<0, \infty 5)$

Com relação à área basal para o conjunto das outras espécies, a situação se inverte entre as duas áreas, sendo maior na área perturbada, $6,27 \mathrm{~m}^{2}\left(1,81 / 1.000 \mathrm{~m}^{2}\right)$, e menor na área não perturbada, $4,70 \mathrm{~m}^{2}$ $\left(1,36 / 1.000 \mathrm{~m}^{2}\right)$. Um dos fatores que pode ter contribuído para este resultado foi o corte de Euterpe edulis no local, que diminuiu a competição e possibilitou condições favoráveis para maior desenvolvimento de outras espécies. Nas duas áreas de estudo Euphorbiaceae foi a familia que se destacou, seguida por Cyatheaceae e Melastomataceae, na área não perturbada, e Lauraceae e Mirtaceae, na área perturbada.

Com relação à área basal total, não houve diferença significativa, ao nivel de 5\%, entre as duas áreas. Este fato demonstra a dinâmica existente em uma floresta, que apresenta diferentes espécies dominantes de acordo com as condições ambientais, havendo sempre alternância entre espécies. 
$\mathrm{Na}$ área não perturbada pelo extrativismo (ANP), foram amostrados 190 indivíduos $\left(55 / 1.000 \mathrm{~m}^{2}\right)$ de Euterpe edulis, valor que correspondeu a $48 \%$ do número total de indivíduos amostrados (393), enquanto que, na área perturbada pelo extrativismo (AP), foram amostrados apenas 32 indivíduos de Euterpe edulis, $11 \%$ do total.

Embora a área basal total não tenha sido significativamente diferente entre as duas áreas, o número total de indivíduos amostrados na área não perturbada (ANP) foi maior que na área perturbada (AP). Este fato pode ser explicado pela grande ocorrência de Euterpe edulis em ANP, espécie representada por muitos indivíduos, mas que, porém, apresenta área basal individual relativamente pequena.

Com ressalvas às diferenças de métodos fitossociológicos adotados e dos critérios de inclusão dos indivíduos arbóreos, pode-se comparar estes resultados com os encontrados por outros autores.

Struffaldi - De Vuono et al. (1989), comparando a estrutura da vegetação em duas áreas da Reserva Biológica de Paranapiacaba, mais e menos afetadas pela poluição, utilizando o método de quadrantes, verificaram que Euterpe edulis foi a espécie dominante no estrato arbóreo de ambas as áreas, contribuindo com mais de $50 \%$ do total de indivíduos amostrados, e que apresentou o maior índice de valor de importância, seguida por Alchornea triplinervea (Euphorbiaceae) e Posoqueria acutifolia (Rubiaceae).

Placci et al. (1992), estudando a estrutura de um palmital no Parque Nacional "Iguazu", na Argentina, verificaram que Euterpe edulis contribuiu com $42,5 \%$ do total de indivíduos amostrados (789/ha - DAP > $5 \mathrm{~cm}$ ) e $19,5 \%$ da área basal total, o que somado à sua elevada freqüência (100\%), conferiu à espécie o maior índice de valor de importância $(23,24)$.

Melo \& Mantovani (1992), em um levantamento fitossociológico de um trecho de mata atlântica de encosta, na llha do Cardoso, Cananéia, SP, verificaram que Euterpe edulis também apresentou o maior índice de valor de 
importância $(31,13)$, contribuindo com $7,58 \%$ da área basal total e $19,96 \%$ do total de individuos amostrados (501/ha - CAP $\geq 8 \mathrm{~cm})$.

Durante o levantamento, foram também medidas as árvores "mortas em pé", inclusive as de Euterpe edulis, cujas bases dos troncos cortados, ainda permaneciam em pé (Tabela 9).

Tabela 9. Área basal de Euterpe edulis e das outras espécies encontradas "mortas em pé" nas áreas não perturbada (ANP) e perturbada (AP), considerando-se indivíduos com DAP $\geq 10 \mathrm{~cm}$. Área total levantada: $3.450 \mathrm{~m}^{2}$.

Indivíduos "mortos em pé"

Área basal $\left(\mathrm{m}^{2}\right)$

Número de indivíduos

ANP

AP

ANP

AP

Euterpe edulis

$0,03 \mathrm{~b}$

1,72 a

$1 B$

$132 \mathrm{~A}$

Outras espécies

1,66 a

$0,04 \mathrm{~b}$

$19 \mathrm{~A}$

$5 \mathrm{~A}$

Total

$1,69 \mathrm{~b}$

1,76 a

$20 \mathrm{~B}$

$137 \mathrm{~A}$

- valores de área basal seguidos por letras minúsculas diferentes, na mesma linha, diferem entre si pelo teste " $t$ " $(p<0,05)$

- valores do número de indivíduos seguidos por letras maiúsculas diferentes, na mesma linha, diferem entre si pelo teste "Mann Witney" $(p<0,05)$

Com relação à área basal dos indivíduos mortos de Euterpe edulis, na área não perturbada, o valor encontrado foi muito baixo, $0,03 \mathrm{~m}^{2}$ $\left(0,008 / 1.000 \mathrm{~m}^{2}\right)$ e na área perturbada, o valor foi bastante alto, $1,72 \mathrm{~m}^{2}$ $\left(0,50 / 1.000 \mathrm{~m}^{2}\right)$, que correspondeu principalmente aos indivíduos derrubados durante as atividades extrativistas, no mínimo, 132 indivíduos com perímetro à altura do peito igual ou superior a $30 \mathrm{~cm}$ (DAP $\geq 10 \mathrm{~cm}$ ). 
Quanto à área basal das outras espécies "mortas em pé", a situação novamente se inverte entre as duas áreas de estudo. A área não perturbada (ANP) apresentou um número maior de árvores mortas, verificando-se uma área basal de $1,66 \mathrm{~m}^{2}\left(0,48 / 1.000 \mathrm{~m}^{2}\right)$, em contraste com a área perturbada, que apresentou apenas $0,04 \mathrm{~m}^{2}\left(0,01 / 1.000 \mathrm{~m}^{2}\right)$. Devido à sua posição topográfica, nos limites da escarpa, a área não perturbada (ANP) serve de anteparo aos ventos carregados de poluentes provenientes do complexo industrial de Cubatão, o que não acontece com a área perturbada pelo extrativismo (AP), que encontra-se mais protegida. Este fator pode ter contribuído com o aumento do número de árvores mortas na área não perturbada pelo extrativismo.

No levantamento realizado por Struffaldi - De Vuono et al. (1989), em áreas mais e menos afetadas pela poluição, na Reserva Biológica de Paranapiacaba, Euterpe edulis foi dominante no estrato arbóreo de ambas as áreas. Estes dados podem indicar que a espécie, em termos de sobrevivência, resiste bem aos efeitos dos poluentes aéreos e, talvez, por isso, na área não perturbada pelo extrativismo foram encontrados poucos indivíduos mortos de Euterpe edulis, em comparação com as demais espécies amostradas.

\subsection{Avaliação do método de transplante de mudas de Euterpe edulis}

\subsubsection{Variação da intensidade de radiação incidente}

A variação da intensidade de radiação incidente fora da floresta (radiação total) é apresentada na Figura 12 e a variação da intensidade de radiação incidente em cada tratamento ( $R A, R M$ e $R B$ ), é apresentada na Figura 13. Os valores apresentados correspondem às médias das leituras realizadas no dia. 
Intensidade de radiação $\left(\mu \mathrm{mol} \cdot \mathrm{m}^{2} \cdot \mathrm{s}^{-1}\right)$

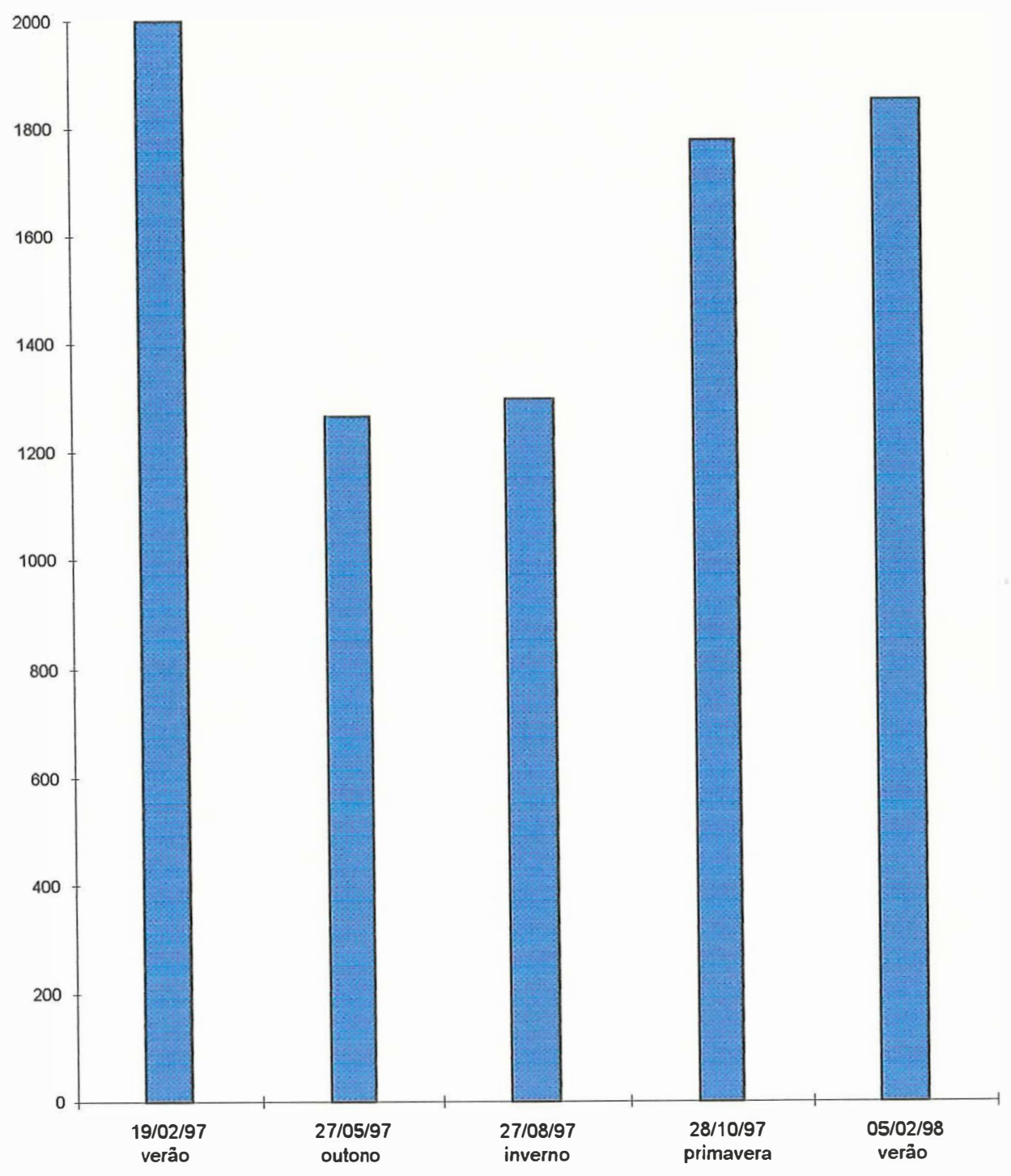

Figura 12 - Médias da intensidade de radiação (PAR) incidente acima das copas das árvores (radiação total), obtidas em 1 dia de cada estação do ano, das 10:00 às 1400 hs, na Reserva Biológica de Paranapiacaba (SP). 


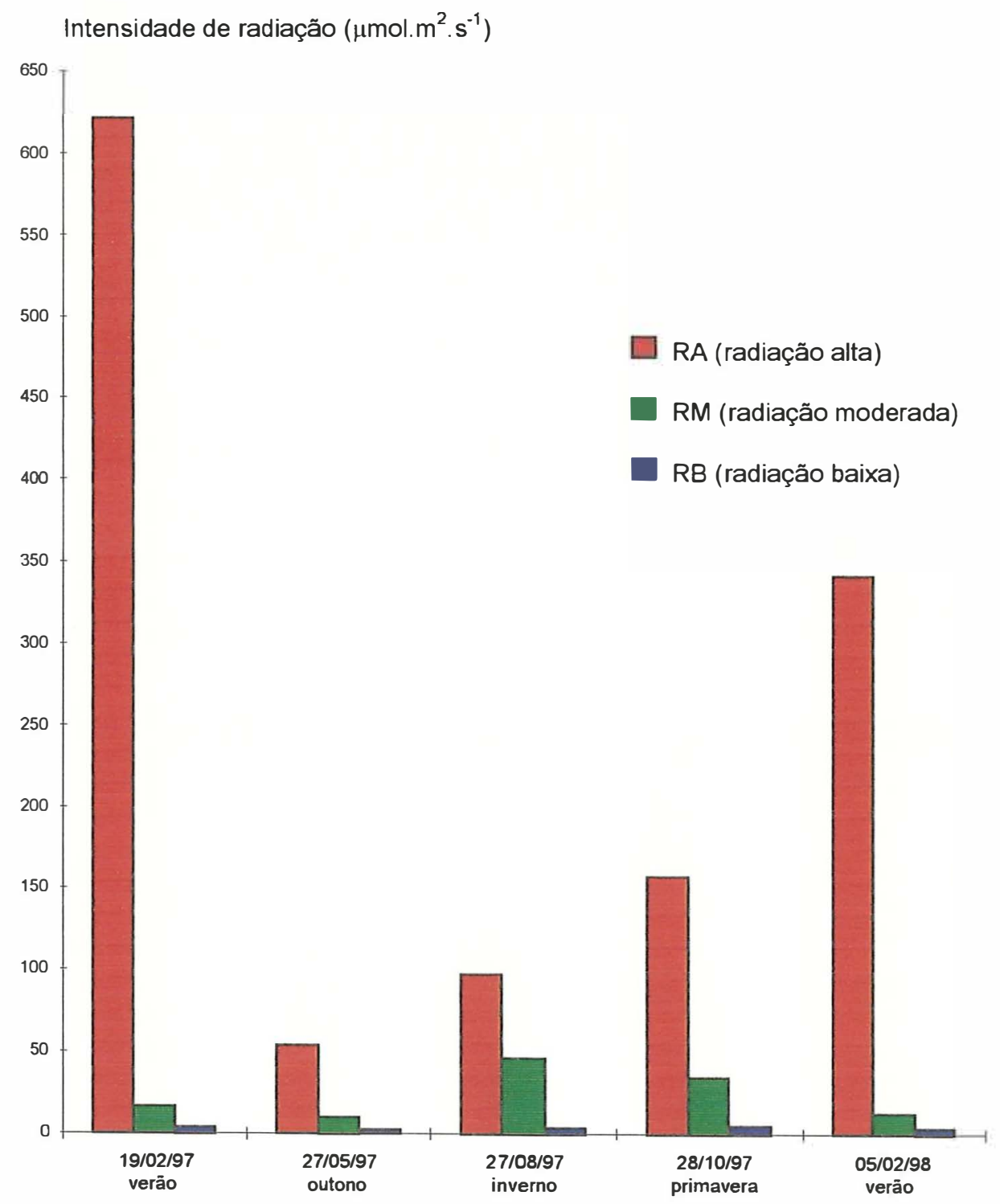

Figura 13 - Médias da intensidade de radiação (PAR) incidente nos tratamentos RA, RM e RB, obtidas em 1 dia de cada estação do ano, das 10:00 às 1400 hs. 
As maiores médias de intensidade de radiação total foram registradas no verão, nos dias 19/02/97 (2.000 $\left.\mu \mathrm{mol} . \mathrm{m}^{-2} \cdot \mathrm{s}^{-1}\right)$ e 05/02/98 $\left(1.850 \mu \mathrm{mol} \cdot \mathrm{m}^{-2} \cdot \mathrm{s}^{-1}\right)$. Já as menores médias foram registradas no outono e no inverno, nos dias 27/05/97 (1.270 $\left.\mu \mathrm{mol} . \mathrm{m}^{-2} . \mathrm{s}^{-1}\right)$ e 27/08/97 (1.300 $\left.\mu \mathrm{mol} . \mathrm{m}^{-2} . \mathrm{s}^{-1}\right)$, respectivamente. A pequena diferença observada entre os dois valores do verão, ou seja, na mesma estação do ano, está relacionada aos horários de leitura, pois, devido à ocorrência de chuva e neblina, nos meses de janeiro e fevereiro de 1998, houve dificuldade em se obter céu limpo em horários equivalentes. No verão de 1997, as leituras foram realizadas às $11: 00$ hs e às $13: 00 \mathrm{hs}$, e, no verão de 1998 , às $10: 00$ hs e às $14: 00$ hs.

Na pequena clareira, considerada como tratamento RA (radiação alta), foi observada a maior média de intensidade de radiação $\left(254,91 \mu \mathrm{mol} \cdot \mathrm{m}^{-2} \cdot \mathrm{s}^{-1}\right)$, ao final do período de experimentação, e também a maior variação nas médias ao longo das estações. Foram verificados valores altos, como $622,25 \mu \mathrm{mol} \cdot \mathrm{m}^{-2} \cdot \mathrm{s}^{-1}$, no verão de 1997 , e valores relativamente baixos, como $54,53 \mu \mathrm{mol} \cdot \mathrm{m}^{-2} \cdot \mathrm{s}^{-1}$, no outono de 1997. Nas parcelas reunidas no tratamento RM (radiação moderada), que apresentou uma média de $24,26 \mu \mathrm{mol} \cdot \mathrm{m}^{-2} \cdot \mathrm{s}^{-1}$, houve uma pequena variação nas médias ao longo das estações, sendo que, a maior intensidade de radiação foi observada no período do inverno $\left(46,67 \mu \mathrm{mol} \cdot \mathrm{m}^{-2} \cdot \mathrm{s}^{-1}\right)$. Já nas parcelas do tratamento RB (radiação baixa), foi observada a menor média de intensidade radiação $\left(3,60 \mu \mathrm{mol} \cdot \mathrm{m}^{-2} \cdot \mathrm{s}^{-1}\right)$ e a menor variação ao longo das estações.

A variação da intensidade da radiação nos tratamentos, ao longo das estações, se deve, à variação na radiação total e à fase fenológica da vegetação que protege as parcelas, principalmente a de perda das folhas, quando há o abaixamento das temperaturas. A parcela do tratamento RA foi influenciada principalmente pela variação da radiação total, sendo comum a incidência direta dos raios solares, sobre as mudas deste tratamento, no verão de 1997, e rara, no outono e no inverno. Já no verão de 1998, esta parcela 
passou a sofrer a influência do sombreamento das copas das árvores do entorno da clareira, resultando em valor muito inferior ao do verão de 1997. As parcelas que compõem o tratamento $\mathrm{RM}$, sofreram pouca influência da variação da radiação total, por estarem protegidas pelas copas das árvores. A maior média de intensidade de radiação foi verificada no inverno, período que coincide com a perda de folhas das copas das árvores. Já as parcelas do tratamento RB, por estarem bem protegidas da incidência dos raios solares, sob as copas das árvores, arbustos e herbáceas, praticamente não sofreram influência da variação da radiação total ou da fase fenológica da vegetação, ao longo das estações do ano.

Lee \& Dawnum (1991), estudando a distribuição da radiação biologicamente ativa em Miami, Flórida, USA, desde o comprimento de onda de $280 \mathrm{~nm}$ (ultra-violeta) a $730 \mathrm{~nm}$ (vermelho-extremo), verificaram que, na faixa da radiação fotossinteticamente ativa (PAR - 400 a 700 nm), há um decréscimo na intensidade da radiação total do verão para o inverno, de $2.224 \mu \mathrm{mol} \cdot \mathrm{m}^{-2} \cdot \mathrm{s}^{-1}$ para $1.520 \mu \mathrm{mol} \cdot \mathrm{m}^{-2} \cdot \mathrm{s}^{-1}$.

Turnbull \& Yates (1993), estudando a intensidade da radiação (PAR) em uma Floresta Pluvial Subtropical, na Austrália, verificaram resultados semelhantes aos encontrados no presente estudo. Os autores constataram uma grande variação para a condição de clareira, tanto ao longo do dia, quanto ao longo dos meses. No centro da clareira, foram registrados valores abaixo de $30 \mu \mathrm{mol} \cdot \mathrm{m}^{-2} \cdot \mathrm{s}^{-1}$, durante 3 meses, e valores de até $400 \mu \mathrm{mol} \cdot \mathrm{m}^{-2} \cdot \mathrm{s}^{-1}$, em outros meses. $\mathrm{Na}$ margem de clareira, foram registrados valores abaixo de $20 \mu \mathrm{mol} \cdot \mathrm{m}^{-2} \cdot \mathrm{s}^{-1}$, durante 7 meses, e valores de até $200 \mu \mathrm{mol} \cdot \mathrm{m}^{-2} \cdot \mathrm{s}^{-1}$, em outros meses. Para a condição de sub-bosque, os autores observaram uma variação muito pequena, constatando uma média diária de $5 \mu \mathrm{mol} \cdot \mathrm{m}^{-2} \cdot \mathrm{s}^{-1}$, durante quase todo o ano. 
4.2.2 Sobrevivência e crescimento das mudas

Os gráficos da Figura 14 apresentam valores referentes à sobrevivência e ao crescimento das mudas de Euterpe edulis que foram transplantadas nos locais dos tratamentos RA, RM e RB. Na Figura 15, pode-se observar o aspecto geral de tais mudas, 17 meses após o transplante, quando as diferenças em altura, diâmetro e aspecto geral das folhas tornaram-se mais evidentes. A Tabela 10 apresenta os valores finais de sobrevivência e crescimento das mudas de Euterpe edulis, 19 meses após o transplante.

a) Sobrevivência

Com relação à sobrevivência, houve diferença significativa, ao nivel de $5 \%$, somente entre os resultados obtidos para as mudas pertencentes aos tratamentos RA e RM, que apresentaram a menor e a maior porcentagem de sobrevivência, respectivamente (50\% e $95 \%$ ). O valor obtido para as mudas do tratamento RB não diferiu significativamente dos valores dos demais tratamentos, apresentando $80 \%$ de sobrevivência (Tabela 10).

Observando a Figura 14, verifica-se que, até 3 meses após o transplante das mudas, a sobrevivência permaneceu em $100 \%$, em todos os tratamentos.

No tratamento RA, o início da mortalidade ocorreu no outono, entre os meses de abril e maio de 1997. Logo após o transplante, as mudas deste tratamento estiveram submetidas a uma forte intensidade de radiação (Figura 13), verificando-se, durante os trabalhos de campo, que $80 \%$ das mudas apresentavam sintomas de queima das folhas. Provavelmente, este foi o principal motivo da mortalidade verificada neste período. Com a chegada do outono, houve uma redução nos valores de intensidade de radiação e de temperatura, o que permitiu uma recuperação das plantas, evitando o aumento da mortalidade no tratamento. A partir do mês de setembro, a intensidade de 

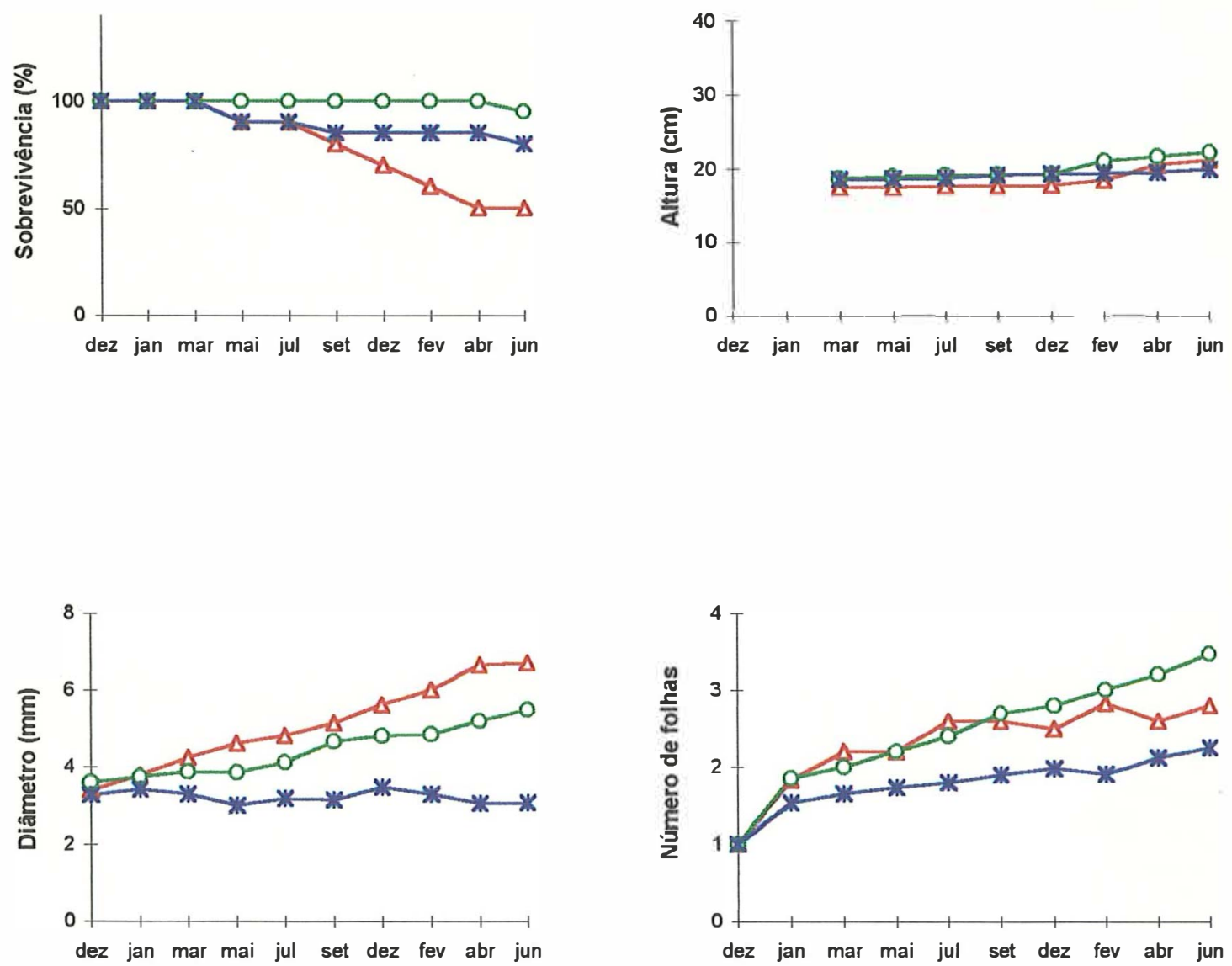

$\smile$ RA (radiação alta) $\multimap$ RM (radiação moderada) $\rightarrow$ RB (radiação baixa)

Figura 14 - Sobrevivência e crescimento das mudas de Euterpe edulis transplantadas nas parcelas dos tratamentos RA (radiação alta), RM (radiação moderada) e RB (radiação baixa). Periodo de experimentação: 19 meses. 

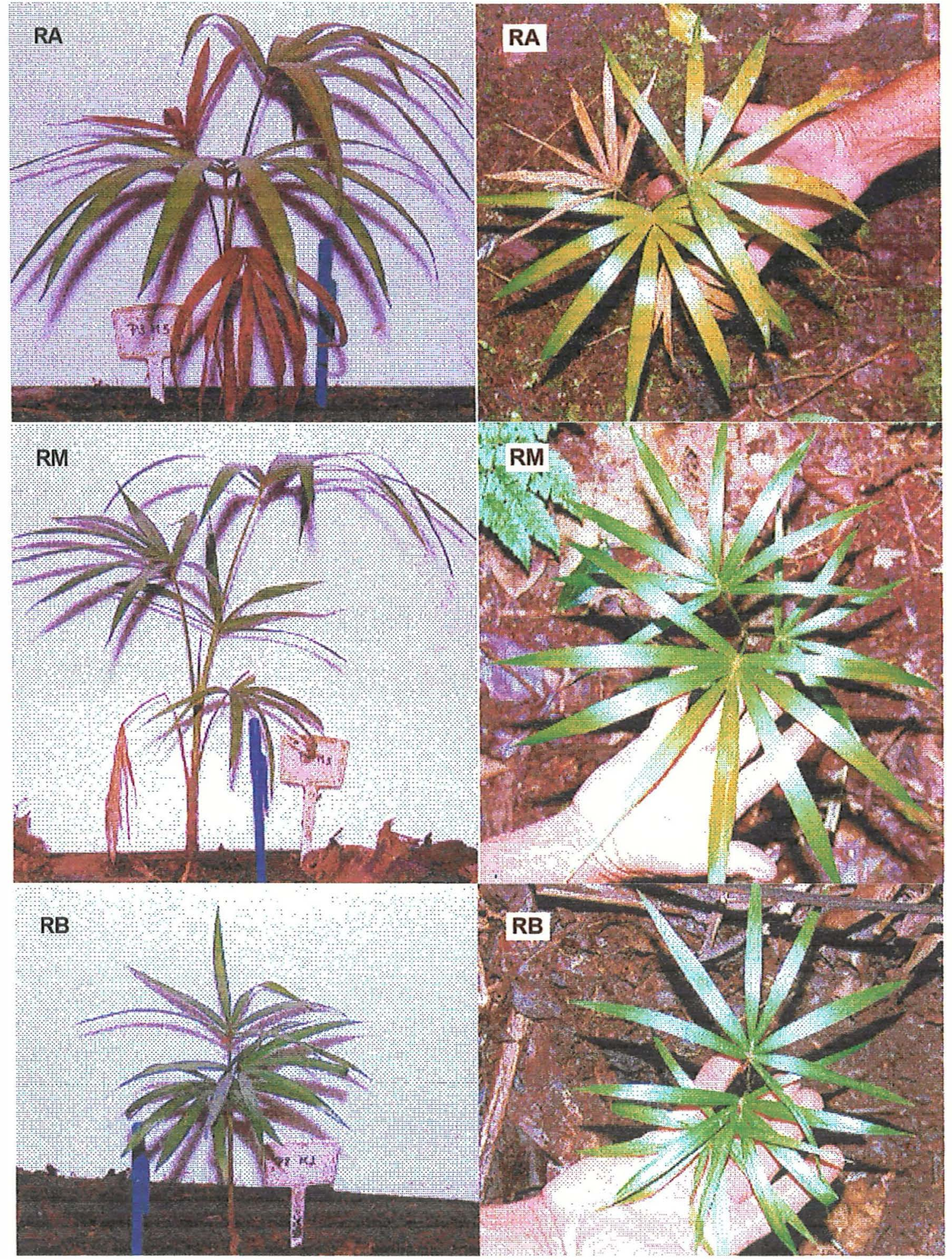

Figura 15 - Aspecto das mudas de Euterpe edulis, aos 17 meses, evidenciando as diferenças em altura, diâmetro e aparência geral das folhas. Tratamentos: RA (radiação alta), RM (radiação moderada) e RB (radiação baixa). 
Tabela 10. Valores finais de sobrevivência e crescimento das mudas de Euterpe edulis que foram submetidas aos tratamentos RA (radiação alta), RM (radiação moderada) e RB (radiação baixa). Período de experimentação: 19 meses.

\begin{tabular}{|c|c|c|c|}
\hline \multirow[t]{2}{*}{ Parâmetros analisados } & \multicolumn{3}{|c|}{ Tratamentos } \\
\hline & RA & $\mathrm{RM}$ & RB \\
\hline Sobrevivência (\%) & $50 \mathrm{~b}$ & $95 \mathrm{a}$ & $80 a b$ \\
\hline Altura $(\mathrm{cm})$ & $21,10 a$ & $22,15 a$ & $19,12 \mathrm{a}$ \\
\hline Diâmetro (mm) & $6,70 \mathrm{a}$ & $5,49 b$ & $3,06 \mathrm{C}$ \\
\hline Número de folhas & $2,80 a b$ & $3,47 a$ & $2,25 \mathrm{~b}$ \\
\hline Número de folíolos & $8,40 \mathrm{a}$ & $7,74 \mathrm{a}$ & $6,50 \mathrm{~b}$ \\
\hline Largura do folíolo central & 1,32 a & $1,16 \mathrm{a}$ & $0,79 \mathrm{~b}$ \\
\hline Comprimento do folíolo central $(\mathrm{cm})$ & 17,74 a & $16,34 a$ & $12,01 b$ \\
\hline Peso seco da parte aérea (g) & $2,93 a$ & $1,57 \mathrm{~b}$ & $0,52 \mathrm{c}$ \\
\hline Peso seco das raizes (g) & 0,96 a & $0,47 b$ & $0,12 \mathrm{c}$ \\
\hline Número de raízes & 8,40 a & $6,47 \mathrm{~b}$ & $3,44 \mathrm{C}$ \\
\hline Comprimento de raízes $(\mathrm{cm})$ & 6,81 a & 6,69 a & $6,49 a$ \\
\hline
\end{tabular}

- valores seguidos na linha pela mesma letra não diferiram estatisticamente pelo teste Tukey $(p<0,05)$. 
radiação no tratamento $\mathrm{RA}$ começou novamente a apresentar valores altos. Desta vez, as mudas foram submetidas a um período maior de alta intensidade de radiação, que se prolongou até o verão de 1998, resultando na grande mortalidade verificada ao final do período de experimentação $(50 \%)$. Novamente foi verificado o sintoma de queima das folhas.

Apesar da mortalidade em RA ter sido mais acentuada que nos outros tratamentos, o índice de sobrevivência pode ser considerado satisfatório para esta condição de alta intensidade de radiação. Nogueira Jr. et al. (1996), testando a interação entre sombreamento e umidade do solo, no estabelecimento de plântulas de Euterpe edulis, constataram total mortalidade no tratamento a pleno sol e alta mortalidade $(40 \%)$ no tratamento com solo saturado em água. No entanto, os autores observaram que a mortalidade das mudas foi bem menor ( $6 \%$ ) nos tratamentos com menor sombreamento e solo saturado, indicando haver uma interação positiva entre os dois fatores. Esta interação pode indicar que as mudas de Euterpe edulis, na Reserva Biológica de Paranapiacaba, talvez possam resistir a maiores níveis de radiação, uma vez que a umidade do solo é alta, devido ao elevado índice pluviométrico e à freqüente neblina que ocorrem na região. Este resultado é de grande interesse para os trabalhos de recuperação das áreas afetadas pelo extrativismo, uma vez que, em vários locais, as atividades extrativistas provocaram a abertura de clareiras no interior da floresta.

As mudas do tratamento RM apresentaram ótimos índices de sobrevivência, que permaneceram em $100 \%$ até o $17^{\circ}$ mês, caindo para $95 \%$ na última leitura, 19 meses após o transplante. A mortalidade, verificada ao final do experimento, não esteve associada à intensidade da radiação incidente no tratamento. Durante a amostragem de campo, verificou-se morte por dano mecânico, causada pela queda de folhas de embaúba (Cecropia sp).

A mortalidade das mudas nas parcelas que constituíram o tratamento RB, foi causada, em sua maioria, pela ação de microrganismos, que provocaram 0 
apodrecimento do colo da planta. Não foi observado nenhum sintoma que pudesse estar relacionado diretamente à baixa intensidade de radiação incidente.

De uma maneira geral, estudos que relacionaram sobrevivência de Euterpe edulis com luminosidade, concordam que existe uma alta mortalidade em plantios a pleno sol, tolerância em níveis relativamente altos de radiação e maior sobrevivência em locais mais sombreados (Nogueira, 1986; Yamazoe et al., 1986; Bovi et al.,1987; Pinheiro et al., 1988; Yamazoe et al., 1990 e Bovi et al., 1992). Estas conclusões estão de acordo com os resultados obtidos no presente trabalho. Considerando-se os diferentes métodos utilizados por estes autores, o tratamento RA corresponderia aos locais com niveis relativamente altos de radiação e o tratamento $\mathrm{RM}$ corresponderia aos locais mais sombreados, citados pelos autores. Em nenhum desses trabalhos foi testado um tratamento com intensidade de radiação tão baixa como a observada nas parcelas incluídas no tratamento RB.

b) Altura das mudas

A altura passou a ser considerada somente a partir de março de 1997, sendo tomada do colo da planta até o início do limbo da folha mais alta. Decorridos 19 meses após o transplante das mudas, não foi verificada diferença significativa entre os tratamentos (Tabela 10), havendo um crescimento muito lento ao longo dos meses (Figura 14).

Yamazoe et al. (1990), estudando o plantio de Euterpe edulis sob três tipos de vegetação, caracterizados como capoeirão, capoeira e capoeirinha, também não verificaram diferenças significativas na altura das mudas com relação ao nível de sombreamento. Pinheiro et al. (1988), estudando o plantio de Euterpe edulis sob diferentes níveis de desbaste de Pinus kesiya, não 
observaram diferenças significativas com relação a este parâmetro, exceto para o plantio à pleno sol, que apresentou mudas mais baixas.

Todavia, Bovi et al. (1992), estudando o plantio de Euterpe edulis sob mata com limpeza de sub-bosque ( $50 \%$ de insolação) e sem limpeza ( $25 \%$ de insolação), verificaram que a altura média das plantas mostrou-se superior na área mais sombreada, concluindo que a altura está correlacionada negativamente com a taxa de insolação.

No entanto, Reis et al. (1987), estudando o desenvolvimento inicial de Euterpe edulis, sob $20 \%, 40 \%, 60 \%$ e $80 \%$ de sombreamento, proporcionado por sombrites, obtiveram plantas menores nos tratamentos de maior e menor sombreamento.

A comparação entre os resultados desses trabalhos é dificultada pelos diferentes métodos adotados pelos autores, que resultaram em padrões de luminosidade que só podem ser comparados entre os tratamentos de cada trabalho. No entanto, tais resultados podem indicar que Euterpe edulis possui um ponto ótimo de luminosidade para seu crescimento, sendo prejudicado em níveis muito altos, como a pleno sol, ou muitos baixos de luminosidade.

c) Diâmetro das mudas

O diâmetro, tomado a $5 \mathrm{~cm}$ do colo da planta, mostrou uma relação positiva com a intensidade da radiação, apresentando diferenças significativas entre os resultados finais de todos os tratamentos (Tabela 10), que puderam ser observadas já a partir do quinto mês experimentação (Figura 14). As mudas pertencentes à parcela que recebeu maior intensidade de radiação (tratamento RA) apresentaram o maior diâmetro médio, 6,70 mm. As mudas pertencentes às parcelas do tratamento $\mathrm{RM}$, de intensidade moderada de radiação, apresentaram valores intermediários de diâmetro médio, $5,49 \mathrm{~mm}$, e as mudas submetidas ao tratamento RB, de menor intensidade de radiação, praticamente 
não apresentaram incremento ao longo dos meses (Figura 14), o que resultou em um diâmetro médio final bastante inferior aos demais tratamentos, 3,06 mm.

A relação positiva do diâmetro de plantas de Euterpe edulis com a intensidade da radiação incidente também foi verificada por outros autores. Bovi et al. (1992) constatou diferenças acentuadas entre os diâmetros das plantas de Euterpe edulis plantadas sob mata com maior insolação (50\% - com limpeza de sub-bosque) e mata com menor insolação ( $25 \%$ - sem limpeza de sub-bosque). A condição de maior insolação proporcionou um melhor desenvolvimento das plantas, quando considerado este caráter. No experimento de Reis et al. (1987), em que o sombreamento foi proporcionado por sombrites, os autores constataram diâmetros maiores do colo das plantas submetidas ao tratamento de maior insolação ( $20 \%$ de sombreamento) e diâmetros menores do colo para as plantas submetidas ao tratamento de menor insolação $(80 \%$ de sombreamento), $0,97 \mathrm{~cm}$ e $0,63 \mathrm{~cm}$, respectivamente. No levantamento da estrutura da população de Euterpe edulis, realizado no presente estudo, os indivíduos levantados na área perturbada por atividades extrativistas, onde houve maior penetração de luz, possuíam diâmetros maiores, para as mesmas classes de altura, que os indivíduos amostrados na área não perturbada, onde as condições no interior da floresta são de baixa luminosidade.

d) Número de folhas e características da folha mais jovem

Com relação ao número de folhas, houve diferença significativa, ao nível de $5 \%$, somente entre os resultados obtidos em plantas incluídas nos tratamentos $\mathrm{RM}$ e RB, que apresentaram o maior e o menor número de folhas (3,47 e 2,25), respectivamente (Tabela 10). No tratamento RM, além das mudas possuírem mais folhas, foi observada também a melhor uniformidade no incremento de folhas ao longo dos meses (Figura 14). As mudas submetidas à maior intensidade de radiação (tratamento RA) apresentaram médias 
intermediárias, 2,80 por muda, e a maior variação no incremento, com ganhos e perdas de folhas. Este fato está associado à queima das folhas pela radiação, observada com freqüência, somente neste tratamento, ao longo do período de experimentação. No tratamento RB foi verificada a menor média final do número de folhas, 2,25 por muda, e o menor incremento ao longo dos meses, que, contudo, ocorreu com certa uniformidade.

Yamazoe et al. (1990) obtiveram resultados diferentes ao estudar o número de folhas de Euterpe edulis em relação à luminosidade. Os autores constataram maior número de folhas nos tratamentos mais sombreados (capoeirão e capoeira) e menor número de folhas no tratamento menos sombreado (capoeirinha). Já Bovi et al. (1992) não detectaram diferenças significativas no número de folhas das mudas plantadas em mata com maior insolação (com limpeza de sub-bosque) e menor insolação (sem limpeza de sub-bosque).

Chazdon (1986), comparando o crescimento de plântulas de três palmeiras: Geonoma cuneata, Asterogyne martiana, e Geonoma congesta, em uma Floresta Tropical Úmida da Costa Rica, em condições de margem de clareira e sub-bosque adjacente (com dossel fechado), verificou que todas as espécies estudadas apresentaram maior razão de produção de folhas e folhas maiores e mais largas na condição de margem de clareira.

Quanto às características da folha mais jovem (número de folíolos, comprimento e largura do folíolo central), não houve diferença significativa entre os tratamentos RA e RM, somente entre estes e o tratamento RB (Tabela 10). No entanto, somente no tratamento RA foram encontradas mudas com folhas com até 10 folíolos e forma pinada mais definida. No tratamento RB foram obtidas mudas com folhas menos desenvolvidas, com menor número de folíolos, mais curtos e estreitos.

Durante as observações de campo, foi verificada uma pequena diferença entre os tons de verde apresentados pelas folhas das mudas, sendo verde claro 
no tratamento RA, verde no tratamento $\mathrm{RM}$ e verde escuro no tratamento $\mathrm{RB}$ (Figura 15).

e) Peso seco da parte aérea e subterrânea

O peso seco da parte aérea foi significativamente diferente entre todos os tratamentos, sendo os resultados bastante diferenciados e relacionados positivamente com a intensidade da radiação incidente. As mudas do tratamento RA atingiram o peso seco de $2,93 \mathrm{~g}$, em média, para a parte aérea, enquanto que as do tratamento RM e RB apresentaram em média $1,57 \mathrm{~g} \mathrm{e}$ $0,52 \mathrm{~g}$, respectivamente (Tabela 10 ).

Quanto ao peso seco da parte subterrânea, foi verificada uma ótima relação entre este parâmetro e a intensidade da radiação incidente, sendo as diferenças altamente significativas entre todos os tratamentos. O peso seco das raízes foi maior no tratamento $R A, 0,96 \mathrm{~g}$, seguido pelo das mudas do tratamento RM, $0,47 \mathrm{~g}$ e por último pelo das mudas do tratamento $\mathrm{RB}, 0,12 \mathrm{~g}$. O mesmo ocorreu com o número de raízes, sendo obtidas, em média, 8,40 raízes no tratamento $R A, 6,47$ raízes no tratamento $R M$ e 3,44 raízes no tratamento RB. Somente com relação ao comprimento das raízes, não houve diferença significativa entre os resultados. Todos os tratamentos apresentaram mudas com raízes de comprimento semelhante (Tabela 10).

\subsubsection{Considerações silviculturais}

O sistema de transplante adotado, realizado por meio do remanejamento das plântulas de Euterpe edulis no interior da floresta, além de aproveitar - mudas que em condições naturais teriam poucas chances de sobreviver, apresenta uma série de facilidades e vantagens em relação aos demais métodos de plantio. Proporciona economia de material reprodutivo, em 
comparação ao sistema de semeadura a lanço, direto no campo, no qual são utilizadas grandes quantidades de sementes. Evita a etapa de formação de viveiro, ganhando tempo e reduzindo os custos com material e mão de obra, além de propiciar uma melhor adaptação das mudas, pois estas são transplantadas para condições ambientais semelhantes às condições de origem.

Logo no início de seu desenvolvimento, as mudas são retiradas com facilidade do solo, sem causar danos às suas raízes. O transplante feito com raiz nua permite que sejam transportadas grandes quantidades de plântulas, sem excesso de peso, e a utilização de Sphagnum umedecido evita a perda excessiva de água durante 0 transporte. A retirada das plântulas deve ser realizada com critério, pois, de acordo com a literatura, alguns animais alimentam-se do banco de plântulas, atraídos justamente pela grande concentração de mudas destes locais.

Durante o plantio, deve-se evitar o acúmulo de matéria orgânica ao pé da planta, para reduzir a ação de microrganismos, bem como o plantio sob plantas com folhas largas e pesadas, para evitar morte por dano mecânico. Como os locais sombreados apenas pelas copas das árvores mostraram-se ideais para a colocação das mudas, recomenda-se uma limpeza no sub-bosque, mas de forma descontínua, em pequenas áreas ( $16 \mathrm{~m}^{2}$, por exemplo), para que outras espécies não sejam prejudicadas. 


\section{CONCLUSÕES}

O extrativismo predatório de palmito, na Reserva Biológica de Paranapiacaba, afetou consideravelmente o potencial de regeneração natural de Euterpe edulis. Além da drástica redução no número de plântulas, a grande maioria dos indivíduos jovens presentes na área perturbada possuem um impedimento mecânico à polinização, fato que poderá retardar ainda mais a recuperação da área. No entanto, o aumento da luminosidade no interior da floresta, provocado pelas atividades extrativistas, parece aumentar o número de indivíduos jovens recrutados, incrementar o diâmetro das palmeiras e, segundo a literatura, adiantar a fase reprodutiva em plantas de palmiteiro. Sendo assim, o tempo para a recuperação da estrutura da população poderá ser mais curto.

O remanejamento de plântulas de Euterpe edulis mostrou ser um sistema de plantio viável para a recuperação das áreas da Reserva Biológica de Paranapiacaba alteradas pelo extrativismo. Os locais sombreados apenas pelas copas das árvores, com intensidade moderada de radiação, ao redor de $24,26 \mu \mathrm{mol} \cdot \mathrm{m}^{-2} \cdot \mathrm{s}^{-1}$, mostraram ser ideais para colocação das mudas. Os locais de pequenas clareiras, com intensidade de radiação ao redor de $254,91 \mu \mathrm{mol} . \mathrm{m}^{-2} \cdot \mathrm{s}^{-1}$, também podem ser utilizados para o transplante, pois a elevada umidade do solo na região favorece o estabelecimento das mudas. $\mathrm{O}$ diâmetro, o peso seco da parte aérea, o número de raízes e o peso seco das raízes das plantas de palmiteiro apresentaram respostas positivas com 0 aumento da intensidade da radiação. $O$ mesmo não aconteceu com a altura e o 
comprimento das raízes, que não apresentaram diferença estatística entre os tratamentos. As características da folha mais jovem (número de folíolos, comprimento e largura do folíolo central) também mostraram uma relação positiva com a intensidade de radiação incidente. No entanto, o número total de folhas foi afetado por níveis muito altos e muito baixos de radiação, devido à queima das folhas e ao baixo desenvolvimento, respectivamente. 


\section{REFERÊNCIAS BIBLIOGRÁFICAS}

AGUIAR, F.F.A.; SILVA FILHO, N.L. Observações sobre o comportamento de Euterpe edulis Mart. (palmito-doce) em mata ciliar. Revista do Instituto Florestal, v. 4 (único), p.630-633, mar. 1992.

ALVES, M.R.P. Palmeiras: características botânicas e evolução. Campinas: Fundação Cargil, 1987. 129p.

BOVI, M.L.A.; GODOY JÚNIOR, G.; SAES, L.A. Pesquisas com os gêneros Euterpe e Bactris no Instituto Agronômico de Campinas. O Agronômico, v.39, n.2, p.129-174, 1987.

BOVI, M.L.A.; GODOY JUNIOR, G.; VAL, M.R. do; MYAO, L.; CAMARGO, S.B.; VICENTE, N.E.; DIAS, G.S. Eficiência de métodos de semeadura de palmiteiro: efeitos na emergência, sobrevivência e vigor das plantas. Revista do Instituto Florestal, v. 4 (único), p.573-582, mar. 1992.

BUTGNOL, C.A. Escala de desenvolvimento para palmeiras de folhas pinadas. Revista do Instituto Florestal, v. 4 (único), p.583-584, mar. 1992.

CARVALHO, P. E. R. Espécies florestais brasileiras: recomendações silviculturais, potencialidades e uso da madeira. Brasília: EMBRAPA - SPI, 1994. 640p. 
CHAZDON, R. L. Light variation and carbon gain in rain forest understory palms. Journal of Ecology, v.74, p.995-1012, 1986.

COUTINHO, L. M. Contribuição ao conhecimento da ecologia da mata pluvial tropical. Boletim 257, Botânica 18, USP: p.11-219, 1962.

DOMINGOS, M. Aspectos da ciclagem de nutrientes na Reserva Biológica de Paranapiacaba (São Paulo), sujeita aos poluentes aéreos do complexo industrial de Cubatão. São Paulo, 1987. 166p. Dissertação (M.S.) Instituto de Biociências, Universidade de São Paulo.

DOMINGOS, M.; POGGIANI, F.; STRUFFALDI DE VUONO, Y.; LOPES, M.I.M.S. Produção de serapilheira na floresta da Reserva Biológica de Paranapiacaba, sujeita aos poluentes atmosféricos de Cubatão, SP. Hoenea, v.17, n.1, p. 47-48, jun. 1990.

FANTINI, A.C.; REIS, A.; REIS, M.S.; RIBEIRO, R. J.; PORTILHO, W. G.; ODORIZZI, J.; MANTOVANI, A. Caracterização de uma área selecionada como "área de coleta de sementes" de palmiteiro (Euterpe edulis Martius) no Vale do Ribeira - SP. In: Congresso Florestal Brasileiro, 7, Curitiba, 1993. Anais. São Paulo: SBS-SBEF, 1993. p.410-412.

FUNARI, F.L.; STRUFFALDI - DE VUONO; Y.; SALUM, S.T. Balanço hídrico de duas áreas de Mata Atlântica: Reserva Biológica de Paranapiacaba e Parque Estadual da llha do Cardoso (Estado de São Paulo). In: Congresso da SBSP, VI, 1986. Anais. São Paulo: p.95-102.

GRIFFITH, J. Economia da conservação "in situ" de recursos genéticos florestais. IPEF, n.35, p.85-92, 1987. 
HERING, K. G. Natural forest management in the Atlantic Coastal Rain Forest of Brazil. Plant Research and Development, v.40, p.7-23, 1994.

KAGEYAMA, P. Y.; FREIXÊDAS, V.M.; GERES, W. L. A.; DIAS, J. H. P.; BORGES, A. S. Consórcio de espécies nativas de diferentes grupos sucessionais em Teodoro Sampaio - SP. Revista do Instituto Florestal, v.4 (único), p.527-533, mar. 1992.

KAGEYAMA, P.Y.; GANDARA, F.B. Dinâmica de populações de espécies arbóreas: implicações para o manejo e a conservação. In: Simpósio de Ecossistemas da Costa Brasileira, III, Serra Negra, 1994. Anais. São Paulo: ACIESP, 1994. p.1-9.

KLUMPP, A.; DOMINGOS, M.; KLUMPP, G.; GUDERIAN, R. (Resp.) Vegetation module. In: Air pollution and vegetation damage in the tropics - the Serra do Mar as an example. Geesthach: GKSS Forschungszentrum Geesthacht Gmbh, 1997, p.V1-V47. (Final Report 1990 - 1996. German / Brazilian Cooperation in Environmental Researsh and Technology)

LEE, D. W.; DOWNUM, K. R. The spectral distribution of biologically active solar radiation at Miami, Florida, USA. International Journal of Biometeorology, v.35, p.48-54, 1991.

LEE, D. W.; BASKARAN, K.; MANSOR, M.; MOHAMAD, H.; YAP, S. K. Irradiance and spectral quality affect Asian Tropical Rain Forest tree seedling development. Ecology, v.77, n.2, p.568-580, mar. 1996. 
LEITÃO FILHO, H. F. Considerações sobre a florística de florestas tropicais e sub-tropicais do Brasil. IPEF, n.35, p.41-46, 1987.

LOPES, M.I.M.S.; TEIXEIRA, C.B.; COMPTE, V.X.; LIESS, S.; MAYER, R. Litter production in the atlantic forest vegetation of Serra do Mar, Cubatão região, Brazil. In: Simpósio de Ecossistemas da Costa Brasileira, III, Serra Negra, 1994. Anais. São Paulo: ACIESP, 1994. p.87-94.

LORENZI, H. Árvores Brasileiras: manual de identificação e cultivo de plantas arbóreas nativas do Brasil. Nova Odessa: Ed. Plantarum, 1992. 367p.

MATOS, D.M.S. A ecologia de sementes e plântulas do palmiteiro em um fragmento de floresta semidecídua. In: Congresso Nacional de Botânica, XLVII, Nova Friburgo, 1996. Resumos. Nova Friburgo, p.358.

MELO, M. M. R. F., MANTOVANI, W. Composição florística e estrutura de um trecho de Mata Atlântica de Encosta, na llha do Cardoso (Cananéia, SP, Brasil). Boletim do Instituto de Botânica, n. 9, p.107-158, 1994.

NODARI, R.O.; GUERRA, M.P.; REIS, A.; REIS. M.S.; MERIZIO, D. Eficiência de sistemas de implantação de palmiteiro em mata secundária. In: Encontro de Pesquisadores em palmito, 1, Curitiba, 1987. Anais. Curitiba: EMBRAPA-CNPF, 1987. p.165-173.

NOGUEIRA, J. N. Palmito: produção, pré - processamento, e transformação agroindustrial. São Paulo: SIC, 1982. 78p. 
NOGUEIRA JR., L. R.; FISCH, S. T. V.; BALESTERO, S. D. Efeito da umidade do substrato e sombreamento no estabelecimento de plântulas de Euterpe edulis Mart. em viveiro. In: Congresso Nacional de Botânica, XLVII, Nova Friburgo, 1996. Resumos. Nova Friburgo, 1996. p.386.

PLACCI, L. G.; ARDITI, S. I.; GIORGIS, P. A.; WÜTHRICH, A. A. Estrutuctura del palmital e importancia de Euterpe edulis como especie clave en el Parque Nacional "Iguazu", Argentina. Yvyraretá, v.3, n.3, p.93-108, jul. 1992.

PINHEIRO, G.S.; MARIANO, G.; CRESTANA, C.S.M. Estudo do desenvolvimento inicial do palmiteiro Euterpe edulis Mart. (Palmae), sob diversas condições de sombreamento, em plantio de Pinus kesiya Royle ex Gordon. Boletim Técnico do Instituto Florestal, São Paulo, v.42, p.171180, mai. 1988.

REIS, A. Dispersão de sementes de Euterpe edulis Martius - (Palmae) em uma Floresta Ombrófila Densa Montana da encosta atlântica em Blumenau, SC. Campinas, 1995. 154p. Tese (Doutorado) - Instituto de Biologia da Universidade Estadual de Campinas.

REIS, A.; REIS, M. S.; FANTINI, A C. Manejo de rendimento sustentado de Euterpe edulis Martius. In: Congresso Florestal Estadual, 7, Nova Prata, 1992a. Anais. Nova Prata, 1992. p.1226-1241.

REIS, A.; FANTINI, A. C.; REIS, M. S.; GUERRA, M. P. Manejo de rendimento sustentado de Euterpe edulis. Capão Bonito, 1992b. 35p. Apostila de curso. (12 a 14 de março - Fazenda Intervales - Capão Bonito). 
REIS, A.; FANTINI, A. C.; REIS, M. S.; GUERRA, M. P.; NODARI, R.O.; LANG, R.; MANTOVANI, A. Sistemas de implantação do palmiteiro (Euterpe edulis Martius). Revista do Instituto Florestal, v.4 (único), p.710-713, mar. 1992c.

REIS, M. S.; NODARI, R. O.; GUERRA, M. P.; REIS, A. Desenvolvimento do palmiteiro: caracterização até os dezoito meses sob diferentes níveis de sombreamento. In: Encontro de Pesquisadores em palmito, 1, Curitiba, 1987. Anais. Curitiba: EMBRAPA- CNPF, 1987. p.141-149.

REIS, M. S.; FRANCHINI, R. G.; REIS, A.; FANTINI, A. C. Variação no período germinativo em sementes de Euterpe edulis Martius procedentes da região de Morretes - PR. Revista do Instituto Florestal, v.4 (único), p.1252-1255, mar. 1992.

REIS, M. S.; GUIMARÃES, E.; OLIVEIRA, G. P. Estudos preliminares da biologia reprodutiva do palmiteiro (Euterpe edulis) em mata residual do Estado de São Paulo. In: Congresso Florestal Brasileiro, 7, Curitiba, 1993. Anais. São Paulo: SBS-SBEF, 1993. p. 358-360.

RIBEIRO, R. J.; PORTILHO, W.G.; REIS, A.; FANTINI, A. C.; REIS, M. S. O manejo sustentado do palmiteiro no Vale do Ribeira. Florestar Estatístico, v.1, n.3, p.15-16, nov. 1993 - fev. 1994.

RODRIGUES, R. R. (Coord.) Trilhas do Parque da ESALQ: palmeiras. Piracicaba: Departamento de Botânica, ESALQJUSP, 1994. 31p.

SÃO PAULO. Secretaria de Estado do Meio Ambiente. Resolução SMA-12 de 13 de abril de 1992. Diário Oficial do Estado, 25 abr. 1992. Seção 1, 102 
(78). Estabelece normas para a exploração do palmito (Euterpe edulis) no Estado de São Paulo.

SETZER, J. Atlas climático e ecológico do Estado de São Paulo. São Paulo: CIBTU-CESP, 1966. 61p.

SMITH, H. Light quality, photoperception, and plant strategy. Annual Review of Plant Physiology. V.33, p.481-518, 1982.

STRUFFALDI - DE VUONO, Y; LOPES, M.I.M.S.; DOMINGOS, M. Air pollution and effects on soil and vegetation of Serra do Mar, near Cubatão, São Paulo, Brazil. In Proc. Int. Meeting for especialists in air polution effects on forests ecosystems, 14th, Interlaken, Switzerland, 1988. Birmensdorf: UFRO P2.05., 1989. p.396-398.

STRUFFALDI - DE VUONO, Y.; KNOBEL, M. G.; KIRIZAWA, M. Dados preliminares sobre dinâmica das populações dos componentes arbóreo e arbustivo de um trecho de floresta da Reserva Biológica de Paranapiacaba (SP). In: Congresso Latino Americano de Ecologia, II, Caxambú, 1992. Anais. Caxambú: 1992. p.289-290.

TURNBULL, M. H.; YATES, D. J. Seasonal variation in the red/far-red ratio and photon flux density in an Australian Sub-tropical Rain Forest. Agricultural and Forest Meteorology. v.64, p.111-127, 1992.

WALTER, $H$. Vegetação e zonas climáticas: tratado de ecologia global. São Paulo: EPTU, 1986. 325p. 
WHATLEY, J. M., WHATLEY, F. R. A luz e vida das plantas. Trad. de Gil Martins Felippe. São Paulo: EPTU, 1982. 101p.

WHITMORE, T. C. Gaps in the forest canopy. In: Tomlinson, P. B.; Zimmermann, M. H. (Ed.), Tropical trees as living systems. Cambridge: University Press, 1978. Cap. 27, p.639-655.

YAMAZOE, G. S.; MOURA NETTO, B.V.; DIAS, A. C. Comportamento de Euterpe edulis Mart., plantado sob diferentes intensidades luminosas. Boletim Técnico do Instituto Florestal, v.40-a, p.133-141, 1986.

YAMAZOE, G. S.; DIAS, A. C.; MOURA NETTO, B.V.; GURGEL GARRIDO, L.M.A. Enriquecimento de vegetação secundária com Euterpe edulis Mart. Revista do Instituto Florestal, São Paulo, v.2, n.1, p.55-67, 1990. 